\title{
Hvorfor er sproget så svært at forstå når det er så let at forstå?
}

\author{
Torben THRANE \\ Engelsksektionen, Handelshøjskolen i Århus, Danmark
}

In an attempt to unravel the intricate relationships between syntax and meaning, this paper clears a space between entrenched 'formalist' and 'functionalist' positions from which to defend a view of language as a $2 \mathrm{nd}$ order representational system. Building on information-theoretic foundations, it introduces a new first clause on top of the two clauses of Dretske's (1995: xiii) Representational Thesis, thus

All linguistic facts are mental facts (new)

All mental facts are representational facts

All representational facts are facts about informational functions

Concentrating on language interpretation, it argues that the proper place to look for the functionality of language is as a property of the Language Faculty as standardly conceived. It distinguishes $1^{\circ}$ representations (of situations) from $2^{\circ}$-representations (of linguistic structure), claiming that the input to the cognitive interface in language interpretation is a $1^{\circ}$-representation converted from a sequence of $2^{\circ}$-representations at an interface created by a default, abstract representation of the utterance situation.

It argues for a purely representational, as opposed to derivational, approach. The syntactic area discussed is that of argument structure and selection, with special reference to the status of hidden arguments and their place in syntactic representations. It is argued that argument selection is independent of, and prior to, assignment of category, case and thematic roles to constituents, and is purely a matter of the selectional properties of predicates with respect to a parameter of optionality. Four constituent types are recognized, two argumental (Complements and Arguments), two non-argumental (Satellites and Parasites); two obligatory (Complements and Parasites), two optional (Arguments and Satellites).

\section{INDLEDNING}

Sammenhængen imellem syntaks og betydning er et kompliceret emne. Tænk blot på følgende banale modsætningsforhold. Syntaks er svært. Man skal være trænet lingvist for at kunne se den syntaktiske struktur i selv ganske simple sætninger. Det forudsætter forståelse af distributionsanalyse, konstituentidentifikation, klassifikationsprincipper, forskellen imellem form og funktion, forskellen imellem syntaktiske 
funktioner og thet a-roller, og mange andre ting af udpræget teoretisk tilsnit, og det volder selv begavede studerende problemer at holde alle disse ting ude fra hinanden. Betydning, derimod, er let. Selv de dummeste studerende forstår hvad man siger til dem, og det gør de fordi de håndterer distributionsanalyse, konstituentidentifikation, klassifikationsprincipper, forskellen imellem form og funktion, forskellen imellem syntaktiske funktioner og theta-roller, og mange andre ting af udpræget teoretisk tilsnit uden de store problemer. Det er forudsætningen for at forstå hvad man siger.

Med en let omskrivning af Platons problem, Hvordan kan det gå til at sproget er så svært at forstå når det er så let at forstå.

Det er hovedspørgsmålet for denne artikel. ${ }^{1}$ Det er et spørgsmål der giver anledning til at at tage en række fundamentale antagelser om sprogets 'væsen' op til kritisk eftersyn, at sætte fokus på beskrivelsen af det, samt overveje hvad formålet med sådanne beskrivelser kan tænkes at være. Det er selvsagt temmelig tunge emner. Artiklen bør derfor betragtes som en programerklæring, snarere end som den endelige udmøntning af en (ny) sprogteori.

\section{SYNSVINKLER PÅ SPROC}

Der er to fremherskende, overordnede synsvinkler på sprog: sprog skal beskrives og forklares enten som et autonomt system (den 'formelle') eller som et kommunikationsmiddel (den 'funktionelle'). Mit udgangspunkt vil være et tredje: alle sprog - såvel naturlige som kunstige - er repræsentations systemer af en særlig art. Jeg vil derfor først sige noget generelt om repræsentationssystemer.

Jeg vil dernæst introducere den tese - repræsentationstesen - der ligger bag denne synsvinkel. Den har sin oprindelse i arbejder af Fred Dretske, en amerikansk, nu pensioneret, filosof hvis to hovedværker (som jeg ser det), Knowledge and the Flow of Information (Dretske 1981) og Naturalizing the Mind (Dretske 1995) har været stadige inspirationskilder.

Én af de væsentligste ingredienser i repræsentationstesen er den plads den giver til funktionalitet. Det er netop i spændingsfeltet imellem syntaks og betydning at spørgsmålet om sproglig funktionalitet opstår og som dermed er det sted slaget imellem det formelle og det funktionelle paradigme står.

Generelt tror jeg på muligheden for at skabe objektive resultater og give lovmæssige forklaringer på sproglige fænomener gennem anvendelsen af hypotetisk-deduktive metoder; specifikt baserer min brug af disse metoder sig på antagelsen om at betydning er den egenskab ved sproglige tegn der gør at de bærer information, ikke direkte om omverdensforhold, men derimod som input til en række kognitive processer der bruger den til konstruktion og manipulation af mentale modeller - man kunne kalde det se mantisk konstruktivisme. 
Det syntaktiske område jeg vil diskutere i forhold til artiklens hovedpointe er argumentselektion. Jeg vil fokusere på skjulte argumenter og deres forhold til valget af subjekt/objekt, med udgangspunkt i et sparsomt sæt af eksempler fra dansk og engelsk. ${ }^{2}$ Det interessante er hvilken plads de skal have i sprogbeskrivelsen.

\section{RepR $A$ SENTATIONSSYSTEMER}

\section{In the beginning there was information.}

The word came later.

(Dretske 1981: vii)

Dette er min trosbekendelse. Det er ikke min alene - faktisk vinder den større og større udbredelse, som det f. eks. fremgår af Mind and Machines, vol. 13 (2003), et særnummer viet til informationens filosofi. Selvom information fra denne betragtning er universelt og uafhængigt tilstede, bliver den først for alvor interessant når den sættes i forbindelse med systemer der bruger den. Sådanne systemer er repræsentationssystemer.

Et repræsentationssystem er et system der enten ved evolution eller design har som sin fun ktion at bære information om noget andet end sig selv. Et speedometer er designet til at bære information om transportmidlers fart, vores sanser er udviklet til at bære information om vores omgivelser.

Det vigtige her er påstanden om at et system er et repræsentationssystem i kraft af funktionalitet, og at funktionalitet på sin side afhænger af design eller evolution. Motorcykler, slips, vaner og alle mulige andre ting som i semiotikken anses for at være tegn, udelukkes hermed fra klassen af repræsentationssystemer - hverken motorcykler, slips, eller vaner er designet eller udviklet til at bære information om noget andet end sig selv. Det er ikke deres funktion.

Et andet karakteristisk træk ved repræsentationssystemer er at de kan $\mathrm{m}$ i s repræsentere. En røgfane bærer information om vindretning, men den kan ikke misinformere om vindretning. Det kan en vejrhane derimod, hvis den er gammel og rusten, for eksempel.

Dretske inddeler repræsentationssystemer i konventionelle og naturlige systemer. Konventionelle systemer er groft sagt dem der bringes til verden ved design, de naturlige groft sagt dem der er kommet til verden af sig selv, ved evolution.

Han er - som epistemolog - selv mest interesseret i de naturlige. Da han indplacerer sprog blandt de konventionelle har han derfor ikke meget at sige om det. Indplaceringen er da heller ikke umiddelbart og uden videre indlysende. Specielt er det ikke klart hvad han her mener med sprog - det vender jeg tilbage til.

Men der er en anden vigtig skelnen før vi kommer til det - skellet imellem systemiske og tillærte repræsentationsformer. Det afspejler forskellen imellem 'arv' og 'miljø'.

Viseren på en trykmåler kan fortælle os noget om trykket i den kedel måleren er 
forbundet med fordi hele systemet er lavet af materialer der reagerer på trykforskelle på en forudsigelig måde - det er dets a rv. For at lette vores forståelse af hvad det er viseren siger, har designeren udstyret måleren med en skala hvis tal viseren peger på - f. eks. 4. Vi får dermed at vide at trykket i kedlen er 4 atmosfære. Denne direkte aflæsning via en tabel er et eksempel på analog repræsentation - mellemrummene imellem tallene betyder også noget, vi kan sætte decimaler på.

Antag nu at arbejdstrykket i kedlen ligger imellem 2 og 4 atmosfære. Men kedlen er konstrueret til at kunne modstå et langt højere tryk, selvom der er grænser. Der er en sikkerhedsmargen imellem 4 og 7 atmosfære, mens højere tryk udgør en sikkerhedsrisiko. Set fra operatørens side er det d i s s e grænser der er afgørende - det er dem der definerer apparatets funktionalitet, og som hidrører fra systemets miljø. Han har derfor inddelt skiven på trykmåleren i tre felter og malet dem i forskellige farver - grønt siger 'OK', gult siger 'Tjek systemet' og rødt siger 'Så er det UD!'. Det er et eksempel på digital repræsentation. Den funktionelt interessante information er om viseren står i det grønne, det gule eller det røde felt.

Det har designeren af trykmåleren forstået og taget højde for i den nyeste model af måleren. Her er ikke kun tallene væk, men også viseren. I stedet er det hele måleskiven der skifter farve til hhv. grøn, gul og rød tilstand, afhængigt af trykket i kedlen. Disse farver har slået en mængde information sammen under én hat - det er ikke længere muligt at aflæse forskelle i melle m f. eks. 2 og 4 atmosfære. Dette er et ko mplet digitaliseret system. Al funktionel information er komplet digitaliseret information..$^{3}$

Det er en vigtig pointe at al sproglig information er komplet digitaliseret. Det kan f. eks. illustreres for det leksikalske område ved denne lille læsetest, bragt i Information:

En viskdenbaleig unsdelrøgelse lavet af et untivseriet $i$ England har vist, at desrom de to føste og de to sisdte bostgvaer $i$ alle oredne i en tekst er ritgigt pledcaret, spllier det ingen rolle, hvkilen raeføkkelge de øvirge bosgvtaer i oredne kommer. Teksten er fuldt loebsar, selv om andre bogastver kommer huilbtertulter! Det er, fordi vi ikke loeser hvert eneklt botgsav, men ser bildeler af ordet som en hehled, skrev Dablgdaet Infamtiroom i går.

Afkodning af information på det leksikale plan er ikke analog med leksikaliers ortografi. Men bemærk at testen påpeger at man skal kigge to steder i ordet - i begyndelsen og i slutningen. Det afspejler en forskel imellem leksikalsk og grammatisk betydning. Det er vigtigt at se på slutningen af ord (i sprog som dansk og engelsk) for det er her den grammatiske betydning er kodet, i form af fleksiver. Det er vigtigt at se på begyndelsen af ordet for at blive ledt på rette vej mht. indhold.

\subsection{RepraESENTATIONSTESEN}

Den tese Dretske (1995: xiii) forfølger for at kunne forklare vores perceptions- og kognitionssystem som repræsentationssystemer har to klausuler: 
1a) Alle mentale facts er repræsentationelle facts

1b) Alle repræsentationelle facts er facts om informationsfunktioner

Konsekvensen af dem er at det englændere kalder 'the mind' godt nok er hjernen ('the brain') , men hjernen set under en bestemt synsvinkel. Den synsvinkel, nemlig, hvorunder vi anskuer hjernens funktionalitet. Det er et centralt punkt at man ikke kan lære noget væsentligt om et systems f u n kt i o n a lit e t ved at beskrive dets st r u k t u r . Pointen illustreres med et fotografiapparat. Detaljerede redegørelser for linsedimensioner, lukketider og brændvidder forklarer intet om hvordan et fotografiapparat vi r ker. Her aner man konturerne af lingvistikkens slagsmål imellem formalister og funktionalister igen, og det kunne se ud som om jeg med Dretske i ryggen ville stå midt i den funktionalistiske lejr. Det gør jeg ikke, for jeg tror funktionalisterne har kigget efter funktionalitet de forkerte steder.

På den anden side står jeg heller ikke midt i formalisternes. De har nemlig haft blind tillid til at man kan gøre det Dretske siger man i k ke kan. De har begået den fejl jeg i en anden sammenhæng har beskrevet som The Descriptivist Fallacy (Thrane 1992).

\subsection{Den udVidede REPRASENTATIONSTESE}

Som sagt siger Dretske ikke meget om sprog. Hvis man vil bruge hans teoretiske indsigter må man derfor tilpasse dem på en måde så det bliver klart hvordan sprog anskues, og hvad det er ved sprog hans tese kan bruges på. For at præcisere det har jeg indsat en ny førsteklausul foran Dretskes to:

2a) Alle lingvistiske facts er mentale facts

2b) Alle mentale facts er repræsentationelle facts

2c) Alle repræsentationelle facts er facts om informationsfunktioner

Alle lingvistiske facts er mentale facts. Det er en stærk klausul, og ikke én som jeg forventer alle er enige i. For der er tydeligvis facts vedrørende sprog der ikke er mentale. Det er ikke et mentalt fact at man staver til ordet 'sprog' som man gør. Det er ikke et mentalt fact at man kan bruge sprog som kommunikationsmiddel, osv, osv. Det er ikke desto mindre en klausul jeg betragter som central i bestræbelserne på at forklare hvad sprog er, hvordan det er skruet sammen og hvordan det fungerer. Det er når alt kommer til alt sprogets repræsentative funktionalitet der står som det ultimative mål for lingvistiske forklaringer. Ved at melde ud på denne måde bliver det derfor klart at jeg anser lingvistikkens - i modsætning til filologiens og sprogvidenskabens - genstand for at være sprog forstået som repræsentationssystem .

Der er som bekendt flere forskellige opfattelser af hvad sprog er, men én ting er sikker. Der er en forskel imellem sprog forstået som s y s te m og sprog opfattet som forløb (i Hjelmslevs terminologi). Hos Saussure hedder det la ng ue og parole, hos den tidlige Chomsky competence og performance, og hos den senere Chomsky I-sprog og E - s p r o g . Jeg påstår ikke at alle disse par dækker de samme realiteter, endsige de samme teoretiske holdninger eller indsigter, men blot at der som kimen i dem alle ligger en 
erkendelse af at der er en væsentlig skelnen imellem sproget i brug og sproget i hvile.

Med indførelsen af den nye førsteklausul under repræsentationstesen er det klart at jeg hælder mest til Chomskys termpar - og specielt da der bag dem begge gemmer sig anerkendelse af at vi som individer, hver især, besidder en særlig, artsspecifik evne som vi kunne kalde sprogevnen (Chomskys Language Faculty).

Hvis man akcepterer det, og hvis man samtidig akcepterer repræsentationstesens nye førsteklausul, betyder det at man nu må udforske sproget i lyset af repræsentationstesen. Det er det jeg vil gøre.

\subsection{Repraesentationssystemers typologi}

På tværs af inddelingen af repræsentationssystemer i naturlige og konventionelle - der som sagt baserer sig på om de er opstået ved hhv. evolution eller design - kan man inddele dem efter arten af den information de bærer, analog eller digital. Det er en inddeling der falder sammen med Bickertons (1995) skel imellem 1. ordens (1-) og 2. ordens ( $2^{\circ}$-) repræsentationssystemer. Det afgørende for Bickerton er at $2^{\circ}$-systemer har s y n t a k s. Typologien kan fremstilles sådan her:

\begin{tabular}{|c|c|c|c|}
\hline & & Konventionelle & Naturlige \\
\hline $1^{\circ} \mathrm{RS}$ (analoge) & & Måleinstrumenter & Sanser \\
\hline \multirow{2}{*}{$2^{\circ} \mathrm{RS}$ (digitale) } & & & Begreber \\
\cline { 2 - 4 } & Komplet & Sprog & \\
\hline
\end{tabular}

Fig. 1: Repræsentationssystemers typologi

Sprog er herefter rubriceret som et komplet digitaliseret repræsentationssystem, hvilket vil sige at den information sprog bærer (om noget andet end sig selv) er komplet digitaliseret information. Men hvad betyder 'sprog' her? Er det, i den senere Chomskys terminologi, E-sprog, I-sprog eller selve sprogevnen? Herudover er det ikke umiddelbart indlysende at sprog er 'designet' snarere end udviklet, men den diskussion er generel for alle biologiske systemer - som diskuteret af Larry Wright (1976) i hans version af det teleologiske forklaringsparadigme. Det vil jeg lade ligge her. Spørgsmålet om hvilken værdi vi skal tillægge 'sprog' er imidlertid afgørende.

\section{SPROG og SPROGEVNE}

I Chomskys nu nærmest klassiske model af sprogevnen fra 1986 - videre diskuteret af Jackendoff (1997) - er sprogevnen et mentalt, artsspecifikt, autonomt beregningsmodul der kobler lyd sammen med betydning via to overordnede men eksterne grænseflader, én der tager sig af perception og artikulation, én der tager sig af fortolkning og begrebsdannelse: 


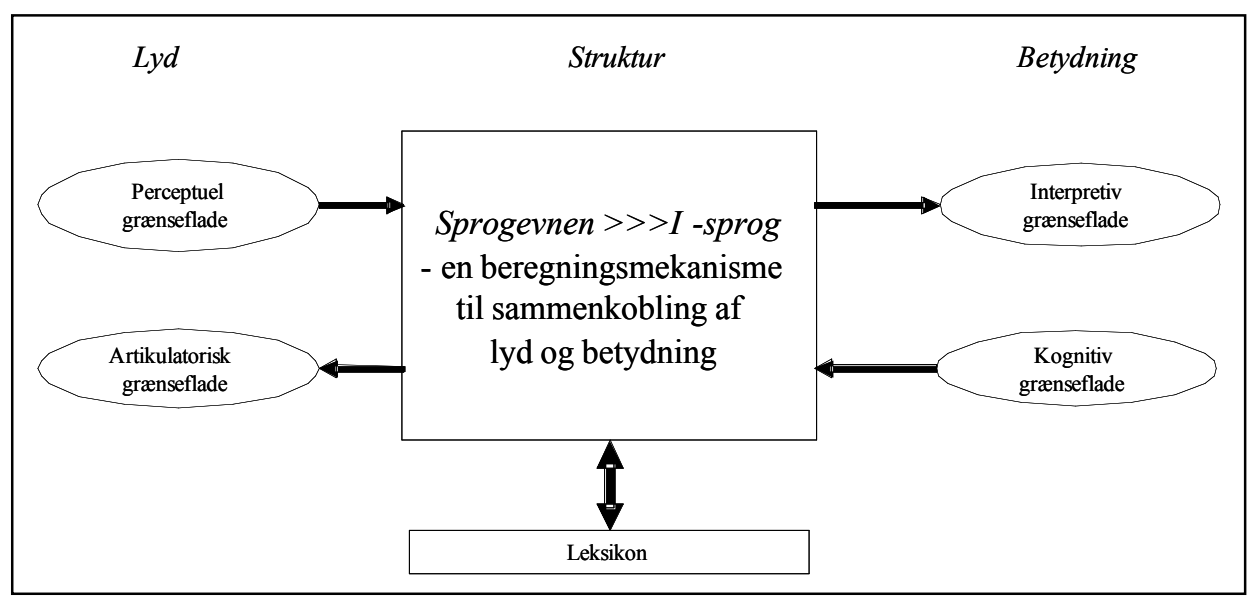

Fig. 2: Den klassiske model af sprogevnen (efter Chomsky 1986)

Sprogevnens initialtilstand er genetisk bestemt og definerer under navnet 'Universal Grammar' det sproglige fællesgods for mennesker. I løbet af individets opvækst, og under miljømæssig påvirkning, gennemløber sprogevnen en række tilstandsændringer for at munde ud i en såkaldt stabil tilstand. Stabile tilstande er I-sprog. $I$-sprog er med andre ord det der ligger bag et individs evne til at producere og forstå sproglige udtryk. Ud over de nævnte grænseflader formodes sprogevnen at have hurtig adgang til et separat lagret leksikon. De socialt, kulturelt eller regionalt definerede konstrukter som vi normalt kalder sprog - dansk, engelsk, swahili, thai, etc. - kalder Chomsky E-sprog og han affærdiger dem som vilkårlige og empirisk uvæsentlige. Det billede kan man købe eller lade være. De fleste herhjemme, har jeg indtryk af, lader være. Jeg køber det - eller i det mindste dele af det. Der hvor jeg har problemer med at købe det helt er i forbindelse med en forklaring på flersproglighed - den omstændighed at jeg er rigtig god til at forstå og tale dansk, rimelig god til at tale og forstå engelsk, men kun tålelig god til at forstå tysk og fransk og elending til at tale dem. Hvor mange $I$-sprog har jeg? Der gemmer sig mange spørgsmål her, som jeg diskuterer andetsteds (Thrane, in press). Her vil jeg blot tage ét frem, som drejer sig om sprogevnens funktion. Den er der ikke mange der har talt om, og følgende ræssonnement skulle gøre det klart hvorfor.

Det er et empiriske faktum at alle medlemmer af arten homo sapiens betjener sig af sprog. Lad os kalde den side af vores mentalitet der sikrer det Universalgrammatik (UG). Det er derfor ukontroversielt at antage at vi har evnen til at ti le g n e os sprog. Lad os kalde manifestationen af denne evne for LAD ('language acquisition device'), og betragte den som en særlig funktion af UG. Hvis LAD nu var den e n e s te funktionelle manifestation af UG ville argumentet for eksistensen af UG være cirkelformet: 
Thrane, Hvorfor er sproget så svært at forstå?

P1 Vi tilegner os alle et sprog fordi vi har evnen til det (UG)

P2 Vi har evnen til det fordi vi har en sprogtilegelsesmekanisme (LAD), en særlig funktion af UG

P3 Det er LAD's e neste funktion at aktivere UG

?K UG eksisterer

Denne non sequitur ${ }^{4}$ er tilsyneladende en konsekvens af at det generativt-kognitive paradigme ser en forklaring på problemet om sprogtilegnelse som formålet for sprogbeskrivelsen, mens problemet om sprogbrug bliver nedprioriteret, ofte ud fra den holdning at sprogbrug er for diffust et genstandsfelt for rationel undersøgelse. Mit relativt naive modspørgsmål hertil er følgende: Hvis vi har en sprogevne, hvorfor skulle vi så antage at den ikke spiller en rolle når vi brug e r sprog? Problemet er blot, hvordan.

Steven Pinker (1995: 290-296) diskuterer den tese at sprogevnen - forstået som sprogtilegnelsesmekanismen LAD - degenererer i løbet af puberteten; endvidere hævder han at det er en ganske normal hændelse for genetisk programmerede systemer. Han forestiller sig også at den 'plads' sprogtilegnelsesmekanismen bruger overtages af andre funktioner, men han siger intet om hvilke. Min antagelse er nu at den funktion UG overtager netop er at skabe de repræsentationer som vores mentalitet konstruerer på basis af sprogligt input og som vi afbilder på virkeligheden. Dette ville være Universalgrammatikkens funktion i sprogbrugen, og den er påkrævet igennem hele individets levetid. Mens evnen til at lære nye ( $E$-) sprog degenerer ${ }^{5}$, konsolideres evnen til repræsentationsmanipulation. Under denne synsvinkel kan vi kalde UG for LID ('languge interpretation device').

Alt dette udgør et $2^{\circ}$-repræsentationssystem - og det kan ses som et autonomt system med grænseflade mod et $1^{\circ}$-system, der er primært i den forstand at det behandler information i form af $1^{\circ}$-input (sanseindtryk) og konstruerer kognitive repræsentationer på basis af en del af det. Sådanne repræsentationer vil jeg kalde $1^{\circ}$-repræsentationer og de er repræsentationer af sit u a ti o n e r. Der er imidlertid typer af $1^{\circ}$-input som vores perceptionssystem klassificerer som sprogligt og som derfor sendes til videre behandling, ikke i $1^{\circ}$-systemet, men i $2^{\circ}$-systemet. De repræsentationer der genereres af det er naturligvis repræsentationer af sproglig struktur, men det output der i sidste ende leveres til den kognitive grænseflade er i k ke. Det er derimod situationsrepræsentationer, og de vil indgå som delrepræsentationer sammen med $1^{\circ}$-repræsentationer genereret fra $1^{\circ}$-input klassificeret som ikke-sprogligt. Dette er et bud på sprogforståelsens kontekstafhængighed. Sammenhængen imellem $1^{\circ}$ - og $2^{\circ}$-repræsentationer vil blive yderligere uddybet i afsnit 5 og 6 nedenfor, når nødvendige forudsætninger er introduceret. Fortolkningen af ethvert sprogligt signal afhænger af information fra to kilder: genereret fra signalet selv, i form af $2^{\circ}$-repræsentationer, og genereret fra situationskonteksten i form af $1^{\circ}$-repræsentationer. Til de sidste hører også talers og tilhørers baggrundsviden og antagelser. Hele modellen kan illustreres således: 


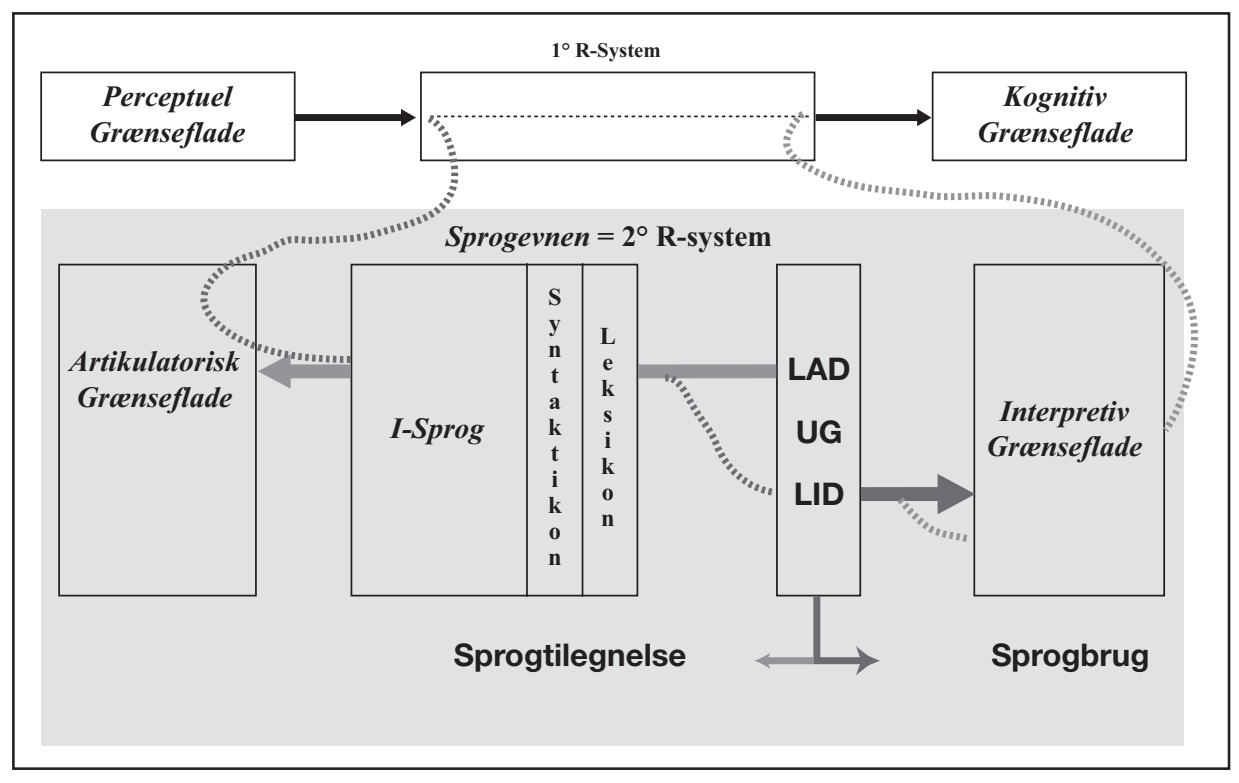

Fig. 3: Model af sprogevnen som sekundært repræsentationssystem

Man kan nu sidestille elementer fra det klassiske skel imellem strukturel, eller 'grammatisk' betydning på den ene side og leksikalsk betydning på den anden, her bl.a. manifesteret ved en tvedeling af leksikon i hhv. et 'syntaktikon' omfattende lukkede ordklasser, flexiver, etc., og et leksikon omfattende 'indholdsord'. Det er samspillet imellem disse to der gør sproget til et komplet digitaliseret repræsentationssystem, hvis generative motor er syntaks i bred forstand:

\begin{tabular}{|c|c|}
\hline Strukturel 'betydning' & Leksikalsk 'betydning' \\
\hline 'Lukkede' ordklasser & 'Åbne’ ordklasser \\
\hline Kombinationsregler & Semantiske relationer \\
\hline Strukturbundethed & Kreativitet \\
\hline Syntaktisk autonomi & Retorisk fleksibilitet \\
\hline $\begin{array}{l}L I D=\text { Kompl } \\
2^{\circ} R \text {-system }\end{array}$ & $\begin{array}{l}\text { seret system }= \\
\text { ks }\end{array}$ \\
\hline
\end{tabular}

Med hensyn til funktionsområder går jeg ud fra disse to antagelser: 
3a) En sætnings syntaktiske og morfologiske tilstande har som deres syste m is ke funktion at generere leksikalsk tilegnede $1^{\circ}$-repræsentationer.

3b) Det er leksikalsk tilegnede $1^{\circ}$-repræsentationer vi sætter i relation til vores opfattelse af virkeligheden.

Det følger af formuleringen i (3a) at vi må kunne redegøre for sætningers syntaktiske og morfologiske tilstande. Og det er netop hvad de bedste formelle sprogteorier giver os redskaberne til at gøre, såsom Government \& Binding/Principles \& Parameters; Generalized Phrase Structure Grammar, Headdriven Phrase Structure Grammer; Lexical Functional Grammar. For dem alle gælder at de har bidraget med væsentlig og detaljeret indsigt i sprogets forskellige strukturelle tilstande. Samtidig har de konkurreret indbyrdes - ofte i forhold til analysen af de samme sproglige data (jeg giver et eksempel nedenfor), men aldrig i forhold til det der iflg. (3a) her anses for at være de påståede tilstandes systemiske funktion. ${ }^{6}$ Det vil jeg diskutere i næste afsnit.

\section{Argumentselektion}

Der er et klassisk minimalt par i engelsk bestående af sætningerne i

4a) Mary is easy to please

4b) Mary is eager to please

Jeg vil kort skitsere fire forskellige teoriers forslag til syntaktisk analyse af (4a), en konstruktionstype hvis prædikat sanktionerer alternationen imellem (4a) og (5a), og som ikke gælder kontrol-prædikater som [eager]:

5a) It is easy to please Mary

5b) *It is eager to please Mary

Dansk har en tæt syntaktisk pendant til (4a), ikke til (4b) - den kræver en præpositionsforbindelse:

6a) Mary er nem at behage

6b) *Mary er ivrig at behage >

6c) Maryerivrig $\{$ til | efter | med | for $\}$ at behage

De samme restriktioner på alternationen imellem (4) og (5) gælder også for dansk:

7a) Det er nemt at behage Mary

7b) *Det er ivrigt at behage Mary

\subsection{Repræsentationsformer}

Alle generative sprogteorier kan betragtes som repræsentationssystemer som her defineret:systemer hvis primære funktion er at bære information om noget a ndet end sig selv. Det kan imidlertid diskuteres hvad de bærer information om. For tilhængere af GB/PP og LFG vil svaret formentlig være 'den menneskelige 
sprogevne'. For tilhængere af GPSG og HPSG vil det derimod snarere blot være 'sprogstruktur'. Uanset svaret søges målet nået gennem udviklingen af et notationssystem ${ }^{7}$ til eksplicitering af (især syntaktisk) s t r u k t u r . Jeg betragter enhver sådan implementering af et repræsentationssystem som en repræsentation s form .

Den tidligste generative analyse af tough-sætninger som (4a) er Postal (1971), der tilskrev sådanne sætninger de to transformationelt forskellige derivationer i (8b) og (8c) fra dybdestrukturen (8a):

8a) $\left[_{\mathrm{S}}\left[_{\mathrm{NP}}\right.\right.$ It ${ }_{\mathrm{S}}$ (for someone) to please Mary $]\left[_{\mathrm{VP}}\right.$ is easy $\left.]\right]$

$8 \mathrm{~b}) \Rightarrow$ It is easy (for someone) to please Mary (ved E x t r a p o s it i o n)

$8 \mathrm{c}) \Rightarrow$ Mary is easy (for someone) to please (ved E x $\mathrm{t} r$ a p o s i t i o n fulgt af It-replacement; det var dette kompleks af transformationer der fik navnet tough-movement)

Med senere artikulationer i GB/PP af kasus- og $\theta$-teori som særskilte grammatiske moduler løb denne klassiske analyse ind i paradokser, enten i forhold til $\theta$-teori eller i forhold til kasusteori.

Uden at gå dybt ind i de tekniske detaljer er problemet i kasusteori det at konstituenten [Mary] ikke kan være flyttet fra den indlejrede objektsposition hvor [please] har tilskrevet den akkusativ, til subjektspositionen i matrixsætningen, hvor den er strukturelt markeret for nominativ. Problemet i $\theta$-teori er i højere grad teoribundet, idet det forudsætter skellet imellem såvel NP- og Wh-flytning som A- og A'-kæder og de forskelle der er imellem dem mht. rolletilskrivning. Den (ikke særlig elegante) løsning Chomsky (1981: 312) selv foreslår (baseret på arbejder af Nanni 1980) er at betragte [easy-to-please] som en reanalyseret leksikalsk størrelse. For detaljeret diskussion af disse problemer, se Jones (1983). Hicks (2003) er et godt forsøg på at løse dem i en minimalistisk kontekst.

I modsætning til GB/PP tillader hverken GPSG, HPSG eller LFG flytning eller andre transformationer og har derfor ingen problemer med at håndtere eksempler som (4a), der $\mathrm{i}$ alle tre teorier er et tilfælde af langdistanceafhængighed. Herudover forudsætter analysen af langdistanceafhængigheder i GPSG/HPSG antagelsen af et såkaldt 'slash' (noteret ved ' $/$ ') - et træk ved en kategori der angiver at den 'mangler noget' for at være mættet. Da ingen af disse teorier har prætentioner om at være kognitive nytter det imidlertid ikke noget at spørge til hvilken repræsentationel status 'slash'-træk måtte have. De er blot deskriptive mekanismer. 
Thrane, Hvorfor er sproget så svært at forstå?

9a)

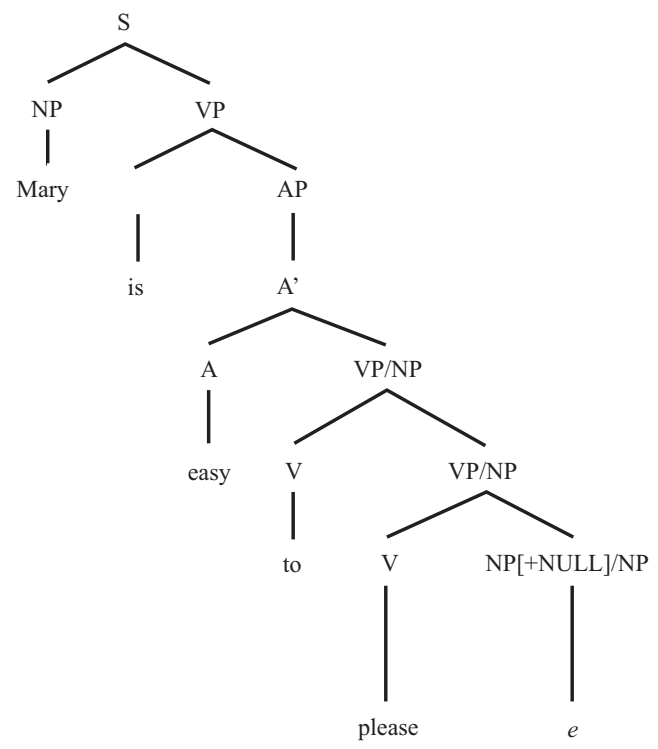

GPSG repræsentationen af Mary is easy to please efter Gazdar et al. (1986: 151)

9b)

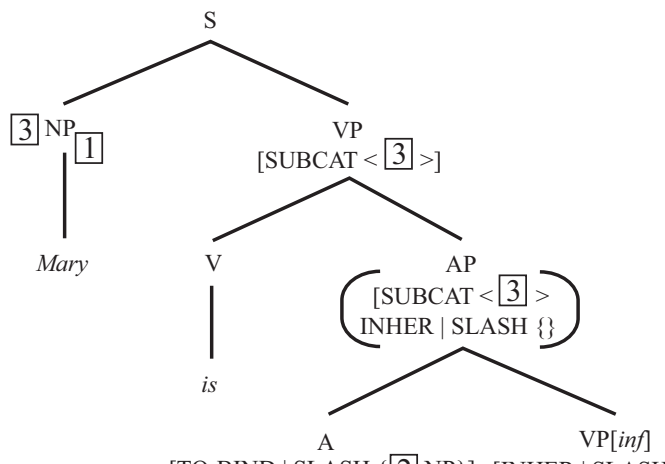

[TO-BIND | SLASH $\{2$ NP $\}]$ [INHER | SLASH $\{2\}$ ]

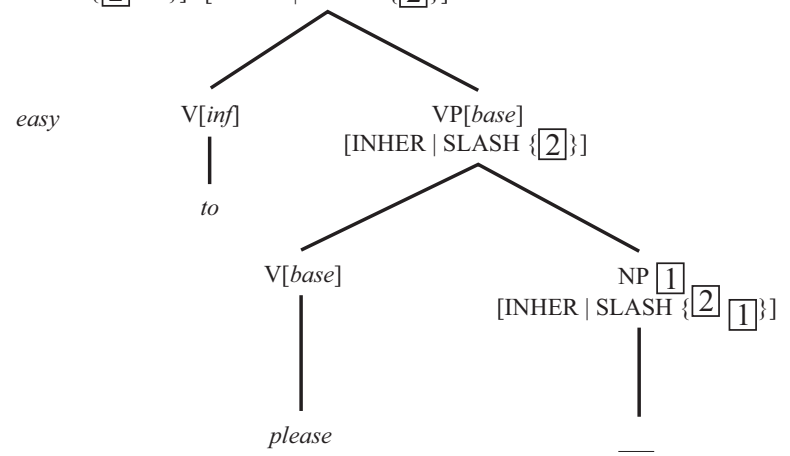

HPSG repræsentationen af Mary is easy to please efter Pollard \& Sag (1994: 168) 
LFG, der som GB/PP betegner sig selv som en kognitiv teori, analyserer sætninger med tough-prædikater som tilfælde af langdistanceafhængigheder hvor der samtidig består en kontrolrelation imellem matrixsubjekt og indlejret objekt. Til gengæld er der i LFG-kredse ikke konsensus om, hvilken af de to former for kontrol - anaforisk og funktionel - som teorien anerkender, der er på tale. Funktionel kontrol er lokal og kræver et kontrollerende element; anaforisk kontrol kræver ikke et kontrollerende element og kan være en langdistancerelation (Mohanan 1983). Fortolkningsmæssigt har forskellen imellem disse to former for kontrol dog ikke umiddelbart nogen konsekvenser da der i begge tilfælde er tale om at etablere identiteten af referenten for et ikke-udtrykt argument, enten via en kontrolligning (f-kontrol) eller blot som værdi af PRO (a-kontrol). LFG afviger fra andre generative teorier ved at henvise information om konstituentstruktur (c-structure) og information om funktionel struktur ( $f$-structure) til to adskilte repræsentationsformer. I (10) er $\mathrm{PRO}_{a r b}$ et fonetisk tomt element med vilkårlig reference, mens $\mathrm{PRO}_{i}$ er et funktionelt kontrolleret tomt element, undertiden blot noteret som '[ ]'. Buen markerer kontrolrelationen. Bemærk at indekseringen er nødvendig for at identificere referenten som Mary; deraf usikkerheden om hvorvidt vi har at gøre med anaforisk eller funktionel kontrol:

10)

$c$-strukture:

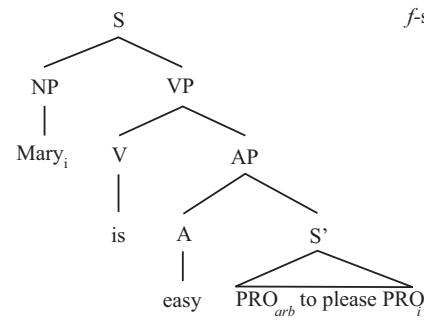

-strukture:

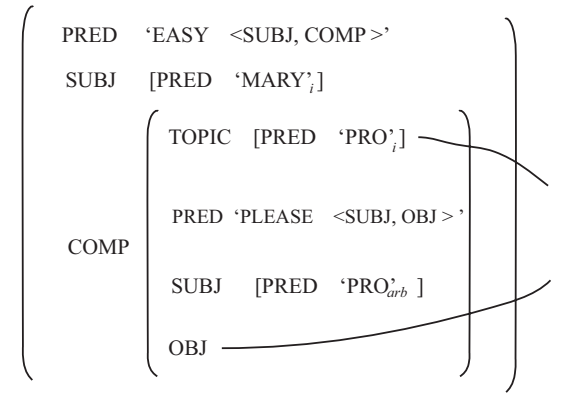

LGF repræsentationen af Mary is easy to please $f$-strukturen efter Dalrymple \& King (2000: 12)

Det er således klart at der kan gives præcise forslag til en formel syntaktisk analyse af toughsætninger. Det anfægtes ikke af den omstændighed at modstriden imellem s æ $\mathrm{n}$ i n g e n s syntaks og de selvpålagte begrænsninger på repræsentationsformens syntaks skaber vanskeligheder for GB/PP.

Til gengæld anes konturerne af et paradoks når man betragter motivationen for disse analyser. En del af den udgøres af det empiriske faktum at det er bet y d n in ge n af (4a) der fremtvinger en fortolkning hvor [Mary] på én og samme tid syntaktisk set er subjekt 
for [is easy] og objekt for [please]. Men hvis repræsentationerne i (8) og (10) på den ene side er alternative repræsentationer af den menneskelige sprogevnes håndtering af inputstrengen (4a), mens på den anden side (9) 'kun' er alternative repræsentationer af inputstrengens struktur, hvorfor er de så i det store og hele en s ? Paradokset kan i noget simplistisk form formuleres således:

11a) inputstreng $\rightarrow(8) /(10) \rightarrow$ fortolkning

11b) inputstreng $\rightarrow$ fortolkning $\rightarrow(9)$

Hvis repræsentationerne i (11a) leder til fortolkning mens i (11b) fortolkning leder til - groft sagt - identiske repræsentationer, er repræsentationens rolle i forhold til fortolkningsprocessen uafklaret.

Det samme kan siges om fortolkningsprocessen selv. Hvordan den forløber er fortsat en gåde, men en gængs antagelse under kendte forudsætninger er at elementer identificeret i inputstrengen matches imod mentale leksikonposter der bl. a. rummer information om syntaktisk konstruktionspotentiale. Det ville i det konkrete tilfælde betyde at leksikonposten for [easy] bl. a. rummer syntaktisk information om at etablere referentiel identitet imellem matrixsubjekt og det skjulte, indlejrede objekt i tilfælde som (4a), ligesom for eksempel [pretty]:

12a) Mary is pretty to look at

12b) *It is pretty to look at Mary

Derimod kan leksikonposten for [pretty] ex hypothesis ikke rumme information der tillader det som prædikat i ekstraponerede sætninger som (12b), i modsætning til [easy]; [pretty] kræver et argument - og ikke et ekspletiv - som subjekt. Men ikke alle er klar over det, f. eks. ikke Lord Northcliffe i hans beskrivelse af slaget ved Verdun, 4. marts 1916:

13) Close by us is a hidden French battery, and it is pretty to see the promptitude with which it sends its screaming shells back to the Germans (www.firstworldwar.com/source/ verdun_northcliffe.htm)

Forudsætningen om 'rigide' leksikonposter holder næppes, hvilket jeg ser som en naturlig konsekvens af sprogets komplet digitaliserede natur. Sprogforståelse fordrer en dynamisk, on-line tilgang til fortolkningsteori baseret på en opfattelse af leksikonposter som (mentale repræsentationer af) t y p e r der rummer komplet digitaliseret information om strukturelt potentiale. ${ }^{9}$ Det er i den forbindelse vigtigt at fastholde at potentialet er under konstant feed-backpres fra konkrete aktualiseringer. Ambitionen er derfor at finde en notation for den aktualiserede information.

En simpel repræsentation af (4a) på basis af den hidtil diskuterede information kunne derfor være denne: 
14)

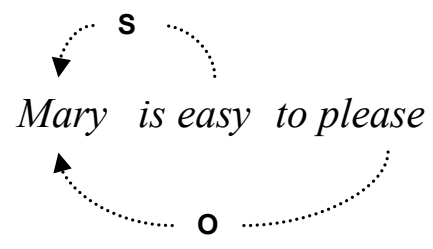

I (14) behandles de grammatiske relationer 'subjekt' (S) og 'objekt' (O) som primitiver, styret af hhv. [is easy] og [please]. Men det er fortsat et ubesvaret spørgsmål om, og i givet fald i hvilken forstand, de bærer fortolkningsinstruktion. Som rent syntaktiske relationer er deres funktion at strukturere det sproglige signal selv. Hvis det er korrekt - som normalt antaget - at der er fortolkningssammenfald imellem (14) og (15)

15)

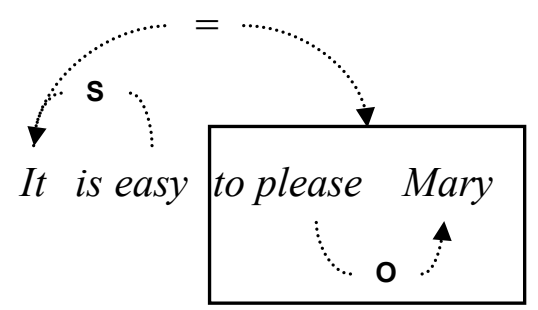

spiller [Mary]s status som subjekt i (14) tilsyneladende ingen fortolknings mæssig rolle. De grammatiske relationer S og O betragtes derfor også i for eksempel den kasusgrammatiske tradition som afledte (Fillmore 1968, 1977; Anderson 1971, 1977, 1997). I stedet tilskrives de tematiske relationer (AGENS, PATIENS, LOKATIV, etc.) primitiv status i fortolkningsmæssig henseende.

Hvis vi i stedet for de grammatiske relationer betragter de tematiske relationer som bærere af information der er nødvendig for fortolkning, reducerer vi spørgsmålet om modelkonstruktion til et spørgsmål om a rg u m e n t s e le kt i o n. Dermed konfronteres vi straks med to distinkte, men beslægtede, problemer: bestemmelsen af mængde og art af tematiske relationer og optionalitetsklausulen.

\subsection{Skjulte argumenter}

Tematiske relationer/roller, semantiske funktioner/roller, theta-roller, dybde- eller semantiske kasus - kært barn har mange navne. Alle er enige om at de er vigtige, ingen har kunnet give principper for etablering af dem, endsige en nødvendig og tilstrækkelig liste over dem. Der er end ikke enighed om hvorvidt de er syntaktiske (GB/PP), 
semantiske (Gruber 1967; Dowty 1991; Parsons 1995), eller kognitive (Jackendoff 1983; 1987 og gennemgående). Litteraturen om dem er omfattende og her behandlet selektivt og summarisk.

I sit indflydelsesrige bidrag til belysning af emnet skelner Dowty (1991) imellem thematic role types (agent, patient, Locative, instrumental, etc.) og individual the mat ic roles, som f. eks. the 'hitter-role' og 'the killer-role' i sætninger som John hit Bill og John killed Bill. Selvom han forkaster de sidstnævnte som defaitistiske og som brugbare redskaber for interessante generaliseringer, lever de de dog videre - ironisk nok - inden for modelteoretisk semantik, herunder HPSGs version af situationssemantik. Jeg forbigår dem i stilhed med Dowtys begrundelse. De tematiske roller (herefter forstået som typer) kan betragtes enten som selektionsegenskaber ved prædikater eller som afledte fra vores opfattelse af 'prototypiske' situationer (eller evt. begge dele). I førstnævnte tilfælde siges verber at tilskrive deres argumenter én og kun én tematisk rolle (GB/ PP), i sidstnævnte tilfælde ses tematiske roller som relationer imellem situationer og entiteter (som sidenhen formuleret af Parsons 1995: 639).

Men selv som typefortegnelse er listen over tematiske roller både lang og vanskeligt afgrænselig. Dowty opstiller derfor hvad han i overensstemmelse med Eleanor Roschs prototypeteori kalder prototy perolle r - og argumenterer for at der kun kræves to, hhv. PROTOAGENT Og PROTOPATIENT, som grundlag for argumentselektion. Hver prototyperolle er defineret ved en række semantiske træk hvis tilstedeværelse sanktionerer forskellige former for logisk implikation (entailment). Øvrige medlemmer af det traditionelle basisinventar af rolletyper (InSTRUMENTAL, EXPERIENCER, LOCATIVE (evt. delt imellem SOURCE og GOAL), etc.) beskrives som argumenttyper der kombinerer forskellige delmængder af de definerende træk ved de to fundamentale protoroller. Formålet med det resulterende rollehierarki er at give begrundelser for valg af hhv. subjekt og objekt.

Dowtys forsøg på at begrænse antallet af tematiske roller er beundringsværdigt, men næppe tilfredsstillende, i og med det kun er en skinbegrænsning. Alle de gængse tematiske roller (og flere endnu) kan afledes fra de to prototyperoller, der dermed bliver temmelig 'fuzzy' (hvilket han da også selv er den første til at indrømme). Væsentligt anderledes forholder det sig med de semantiske kasusrelationer der udgør rygraden i John M. Andersons kasusteori (1971, 1977, 1997, for blot at nævne nogle milepæle) - et oeuvre som Dowty end ikke nævner i sin historiske gennemgang af emnet. Meget kort skitseret er der fire kasusrelationer, baseret på forskellige kombinationer af to lokalistiske semantiske træk, som tabuleret her:

\begin{tabular}{|l|c|c|c|c|}
\hline \hline case relations: & abs & erg & lOC & abl \\
\cline { 2 - 5 } CASE COMPONENTS & & & PLACE & PLACE \\
\cline { 2 - 5 } & & SOURCE & & SOURCE \\
\hline
\end{tabular}

abs = absolutive; erg = ergative; loc = locative; $a b l=$ ablative

Fig. 4: Semantiske kasusrelationer og deres komponenter (efter Anderson 1997: 170)

Der er ingen begrænsning til max én rolle pr. argument (som i GB/PP, for eksempel). 
Anderson operer desuden tekstligt med de øvrige traditionelle tematiske roller, der lader sig beskrive som komplekser af basale kasusrelationer. Valg af hhv. subjekt og objekt er sekundært i forhold til selektionen af argumenter på basis af Fig. 4. I det hele taget gælder det at tabuleringen dér er definerende for Andersons underliggende lokalistiske kasusteori hvis ekstension er kontroversiel. Ikke desto mindre ser det ud som om Anderson her er på jagt efter generaliseringer på et helt andet abstraktionsplan end det der karakteriserer bestræbelserne på at tøjre de klassiske tematiske roller. Det vender jeg tilbage til i afsnit 5.1.

Forholdet imellem argumentselektion på den ene side og valg af subjekt/objekt på den anden er fortsat uafklaret, men tages op igen i den relevante kontekst i afsnit 6.1. I mellemtiden står det klart at ikke alle argumenter er materielt realiseret i konkrete aktualiseringer, som f. eks. i vores standardeksempel (4a), Mary is easy to please. Her er der et uudtrykt a r g u m e nt tilstede. Iflg. alle de gennemgåede repræsentationsformer ovenfor er dette uudtrykte argument imidlertid også syntaktisk tilstede som subjekt og te m a t is k som (рвото)AGENT i forhold til [please]. Det vil formentlig være korrekt at sige at det er tilstedeværelsen af et argument der motiverer påstanden om tilstedeværelsen af et subjekt.

Spørgsmålet er om vi skal give dette ikke-udtrykte element en plads i repræsentationen af den sproglige struktur (i form af et fonetisk nul-element ved navn $\mathrm{PRO}^{10}$, for eksempel), om det skal gives en plads i den $1^{\circ}$-repræsentation som sætningen bærer instrukser til konstruktionen af (i form af en diskursreferentvariabel (Karttunnen 1976), for eksempel), begge dele, eller ingen af delene. Mere generelt, hvordan skal vi håndtere elementer der i én eller anden kognitiv forstand e r der (eller bør være der), men som ikke er repræsenteret i det sproglige signal. Det er bl. a. det optionalitetsklausulen drejer sig om.

\subsection{Optionalitetsklausulen}

I forbindelse med en yderst kritisk gennemgang af den generative standardmodel afdækker Kornai og Pullum (1989) seks klausuler som konstituerende for X-bar teori, hvoraf én er relevant for min diskussion af argumentstruktur. Den følger af grundantagelsen om at alle konstruktioner er endocentriske - en maksimal projektion kan bestå af sin kerne alene. Uformelt formuleret siger optionalitetsklausulen at ' n o n heads are only optionally present'. Det er en klausul der i senere udviklinger af GB/PP (bare phrase structure, minimalism) sløres ved at kræve at kun 'nødvendig' struktur projiceres. En beslægtet distinktion (siden Tesnières 1959 distinktion imellem 'actant' og 'circonstant') er den imellem argument og adjunkt, der er videreudviklet i forskellige valensgrammatiske sammenhænge (f. eks. Allerton 1982; Schøsler/Talbot 1995 - 98), og som i GP/PP udgør basis for skellet imellem A- og Á- positioner. For alle er det afgørende at kunne bestemme hvilke konstituenter der under en traditionel strukturalistisk synsvinkel s kal være tilstede i en sætning over for dem der k a n være tilstede. 
Thrane, Hvorfor er sproget så svært at forstå?

Den strukturelle grammatiks metode til bestemmelse af en konstituents obligatoriske tilstedeværelse i en given sætning er som bekendt mekanisk og tilsyneladende meget enkel: Konstituenten $K$ er obligatorisk i konstruktion $S$ hviss resultatet $\mathrm{R}$ af at udelade $\mathrm{K}$ fra $\mathrm{S}$ enten ikke har samme distribution som S, eller slet ikke er en konstruktion (dvs. er 'ugrammatisk' eller 'ufuldstændig'). Knyttet til metoden er en - normalt skjult - antagelse om at $\mathrm{R}=\mathrm{S} \div \mathrm{K}$ hvad angår linearitet; fjernelsen af $\mathrm{K}$ efterlader $\mathrm{S}$ med 'hul i'. Men selvom det er enkelt er det ikke uniformt begrundet. Betragt disse sætninger:

\section{6a) Han støvede kommoden af \\ 16b) Festen varede hele natten \\ 16c) Han smadrede kommoden \\ 16d) De dansede hele natten}

Konstituenten [af] i (16a) er obligatorisk fordi den er af kategorien P, og fordi der kræves et medlem af $\mathrm{P}$ i denne position; konstituenten [hele natten] i (16b) er obligatorisk fordi den har den tematiske rolle vaRIGHED, og fordi verbet [vare] kræver et komplement med en tematisk tempusrolle; og konstituenten [han] og konstituenten [kommoden] er obligatoriske i (16c) fordi de har hhv. subjekts- og objektsfunktion, og fordi begge disse funktioner kræves realiseret i en sætningsstruktur med [smadre] som V. Konstituenten [hele natten] i (16d) er fakultativ; dens tilstedeværelse er ikke krævet af noget andet element.

Det er således ikke konstituenten som sådan der er obligatorisk eller fakultativ, men derimod konstituenten som medlem af en bestemt kategori, som bærer af en særlig tematisk rolle, eller som bærer af en særlig syntaktisk fun ktion. ${ }^{11}$ Bortset fra konstituenter som [af] i (16a) kan alle (ikke-verbale) konstituenter karakteriseres ud fra alle tre synspunkter. Men alt efter hvilket af disse tre kriterier man lægger til grund for bestemmelsen af en konstituents optionalitet henviser man den - i det konkrete tilfælde - til tre forskellige strukturelle niveauer, hhv. det leksikalske (16a), det verbale (16b) og det sætningsstrukturelle ('clausal') (16c, d). En sådan mekanisk procedure er tillokkende for en deskriptiv grammatik. Set fra et fortolkningsmæssigt synspunkt er den utilstrækkelig.

\section{INTERMEZZO: SITUATIONER}

Lad mig kort rekapitulere hvad vores mål er: med så få og fordomsfri midler som muligt at identificere og notere den information sætninger bærer i form af $2^{\circ}$-repræsentionertil konstruktion af fortolkningsmodeller i form af $1^{\circ}$-repræsentationer.Blandt de grundlæggende antagelser relevante for dette sted i udviklingen er at sprogstruktur er hierarkisk og rekursiv mens sprogbrug er lineær; at fortolkningsprocessen er algoritmisk; at fortolkningsprocessen indebærer evnen til at afkode hierarkisk struktur fra lineært input, hvis resultat er $2^{\circ}$-repræsentationer; og at denne afkodning er afgørende for konstruktionen af $1^{\circ}$ repræsentationer. 
Bortset fra henvisninger til $1^{\circ}$-repræsentationer er disse antagelser ikke væsentligt forskellige fra de grundlæggende antagelser for GB/PP og senere udviklinger. GB/PPs forskellige 'informationslag' ser i skematisk form således ud:

17)

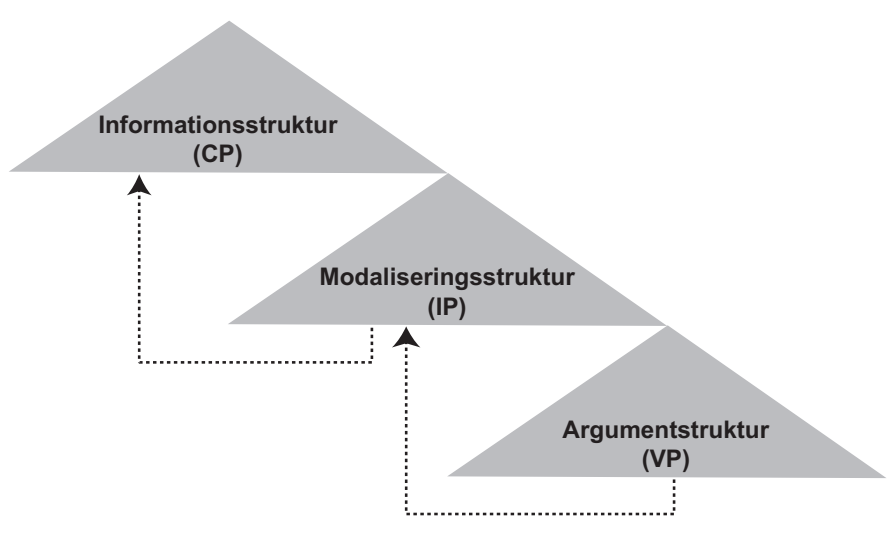

I bunden er der et lag af leksikalsk information der genererer verbers argumentstruktur, på toppen et funktionelt lag der genererer informationsstruktur i form af komplementering, topikalisering og fokusering, og i midten et funktionelt lag der genererer temporale, modale og aspektuelle egenskaber ved strukturen. Hvert af disse lag er i litteraturen underkastet forskellige forslag til en mere finmasket artikulation af den relevante information, såkaldte 'split-CP', 'split-IP' og 'split-VP' analyser af varierende tilsnit, men uanset tilgang er det fælles samlingspunkt antagelsen om en s a m m e $\mathrm{n}$ hæn g e nde struktur hvis enkelte knuder udveksler information via flytning, sammensmeltning og kopiering. Dertil kommer generalisering til intern analyse af NP/DP efter parallelle principper.

Det minimalistiske program har siden midten af 90-erne undersøgt hvilke dele af GB/PP med dens tilhørende modularisering og formulering af principper der er $\mathrm{n} ø \mathrm{dvendige} \mathrm{for} \mathrm{at} \mathrm{give} \mathrm{en} \mathrm{forklaring} \mathrm{på} \mathrm{sprogevnens} \mathrm{indretning,} \mathrm{herunder} \mathrm{spørgsmål}$ om hvorvidt den kan betragtes som 'perfekt' i designmæssig forstand. Omvendt er der mig bekendt ingen der har beskæftiget sig med spørgsmålet om hvorvidt modellen er t i l s t r æ k ke l ig. Ikke desto mindre er det spørgsmål centralt når det drejer sig om at forklare sprogevnens funktion som repræsentationssystem. Netop her bliver det selvpålagte krav om én sammenhængende struktur ikke alene vanskeligt at opretholde; det bliver, så vidt jeg kan bedømme, umuligt. For det ligger i selve det kalkulatoriske koncept at informationsbehandling foregår trinvist ved at den aktiverede processor behandler den globale repræsentation den modtager som input fra sin forgænger i the chain of control'. De syntaktiske operationer nævnt ovenfor bliver derfor i bedste fald at betragte som beskrivelser af relationer i m ell e m repræsentationer, hvilket ikke nødvendigvis er forkert - blot umuligt (jf. s. 11 ovenfor). ${ }^{12}$ 
Thrane, Hvorfor er sproget så svært at forstå?

GB/PP anerkender naturligvis ikke det trin der her anses for det væsentlige i forbindelse med fortolkning - trinnet fra $2^{\circ}$ - til $1^{\circ}$-repræsentation. Hvis dette trin er velmotiveret er GB/PP utilstrækkelig på dette punkt. Ved at acceptere det forpligtes vi til at se nærmere på situationer - og specielt repræsentationer af dem, det jeg ovenfor i afsnit 3 introducerede som $1^{\circ}$-repræsentationer. Situationer er ikke-sproglige hændelser, tilstande og andre 'foregange' (med Ole Togebys 2003 samlende term) som vi kan bruge sprog til at beskrive, omtale og på anden vis meddele os om til andre. Men det ville være naivistisk at betragte denne relation imellem sprog og verden som direkte. Allerede i subsumeringen af en del af den visuelt perciperede virkelighed under betegnelsen 'en situation' ligger der en betydelig kognitiv indsats - skelnen imellem 'figur' og 'grund', valg og fravalg af entiteter og egenskaber, identifikation af del-helhed relationer, genkendelse af et bestemt relationelt forhold imellem de valgte entiteter, anerkendelse af netop dette forhold som konstituerende for dette udsnit som 'en situation', etc. - alt sammen resultatet af en høj grad af digitalisering af information. Pointen er at der til selve situationsbegrebet er knyttet en forestilling om repræsentation - af 1 . orden. Fra et talersynspunkt er en sætning en verbal beskrivelse - ikke direkte af et udsnit af virkeligheden, men af talerens $1^{\circ}$-repræsentation af et udsnit af virkeligheden. Om den er en repræsentation af et udsnit af virkeligheden afhænger af talerens sanddruhed. ${ }^{13}$ Fra et modtagersynspunkt er en sætning en informationskilde til konstruktion af en repræsentation der k a n være en repræsentation af et udsnit af virkeligheden. Om den er det er for så vidt lingvistikken uvedkommende. Hvad der er væsentligt er at en verbal beskrivelse af en situation udgør en y d e r l i g e r e digitalisering af den allerede digitaliserede information der k o n stituerer situationen. Det er denne 'dobbelte digitalisering' der ligger bag synet på sprogevnen som et ko mplet digitaliseret system, og som mig bekendt ikke har nogen plads i andre situationssemantiske fremstillinger.

Austin (1950) skelnede imellem historiske situationer og situationstyper - et skel der blev mødt med betydelig skepsis af Strawson (1965). Historiske situationer kan tøjres i tid og sted og kan derfor ikke gentages. Situationstyper er abstraktioner over historiske situationer. Årsagen til Strawsons skepsis var i alt væsentligt at det er vanskeligt at fastlægge hvilke konstituerende elementer i en historisk situation der kan/ skal abstraheres over. På et tilpas abstrakt abstraktionsniveau er det at drikke te klokken 4 det samme som at spille tennis klokken 5 - begge foregange er historiske situationer der involverer aktivitet, deltagere, tidspunkter, steder, etc. Barwise/Perry (1983: 53) introducerer først "situation-types [which - $t \mathrm{t}$ ] enable us to represent the way things stand in a situation, abstracting away from the where and when" blot for at medgive at " $[t]$ hey could be dispensed with entirely which would allow us to reserve 'situation-type' for what we call in this book event-type" (Barwise/Perry 1983: 55).

På trods af disse vanskeligheder og terminologiske usikkerheder viser skellet sig i en konstruktionssemantisk sammenhæng at være både brugbart og nødvendigt, forudsat det ikke er situationer, men derimod $2^{\circ}$-repræsentationer man anvender det på. Det vil jeg gøre med udgangspunkt i en revurdering af grundlaget for optionalitetsklausulen, hvorefter det kort og godt er konstituenter - og ikke konstituenter som medlemmer 
af en kategori eller som bærere af grammatiske og tematiske funktioner - der er hhv. obligatoriske og fakultative.

\subsection{Obligatoriske og fakultative konstituenter}

Aktuel minimalistisk teori anerkender begrebet numeration som udgangspunkt for en derivation. En numeration er en endelig mængde af leksikalier og grammatiske formativer der, underkastet en række forskellige syntaktiske operationer, i bedste fald resulterer i en derivation der er 'fuldt interpreterbar' både i de fonetiske og de semantiske grænseflader (jf. fig. 2). Da de forskellige operationer numerationens medlemmer undergår i løbet af en derivation forudsætter adgang til deres forskellige fonetiske, grammatiske og semantiske egenskaber, må det formodes at de i en eksplicit repræsentationsform noteres som komplekse trækspecifikationer; men det spiller ikke den store rolle her, hvor det udelukkende drejer sig om fastlæggelsen af argumentstruktur. En numeration er derfor her blot en endelig mængde af leksikalier i grammatisk og ortografisk form.

Set fra et fortolkningsmæssigt synspunkt skal problemet om konstituentidentifikation løses on-line, på basis af information fra de elementer der identificeres i hele inputstrengen (jf. de udfordringer der stilles til parseren ved behandling af såkaldte 'garden-path' sætninger). Da et væsentligt punkt i denne proces er identifikationen af den leksikalske kerne i VP, vil jeg endvidere operere med begreberne domæne og restdomæne i forhold til leksikalske verber, v, indeholdt i en numeration, Num. En mængde, $\left\{\mathrm{k}_{1}, \mathrm{k}_{2}, \ldots, \mathrm{k}_{\mathrm{n}}\right\}$, udgør v's domæne $\left(\mathrm{D}_{\mathrm{v}}\right)$ hvis hvert $\mathrm{k}_{\mathrm{i}}$ er en konstituent genereret over elementerne i Num. Bemærk at $\mathrm{k}_{\mathrm{i}}$ ikke i udgangspunktet nødvendigvis er en sæt n ing s konstituent. V's r e s t d o m æ n e $R_{v}{ }^{i}=D_{v}$ hvorfra er slettet $k_{i}$. Linearitet spiller ingen rolle ved bestemmelsen af $\mathrm{D}_{\mathrm{v}}$ eller $\mathrm{R}_{\mathrm{v}}{ }_{\mathrm{i}}$. Vi kan derfor betragte sætninger som genereret over en mængde af $v+D_{v^{\prime}}\left\{v, k_{1}, k_{2}, \ldots, k_{n}\right\}$ og dernæst systematisk undersøge om $\mathrm{v}+\mathrm{R}_{\mathrm{v}}{ }^{\mathrm{i}}$ også genererer en eller flere sætninger. ${ }^{14}$ Jeg overlader det af pladshensyn til læseren at fuldføre en udtømmende gennemgang, idet jeg blot illustrerer princippet ud fra (16), først fra (16a):

18) i. $\quad$ støvede, af, han, kommoden\}

ii. $\quad$ støvede, af, han, kommoden\}

iii. \{støvede, af, han, kommoden\}

iv. $\{$ støvede, af, han, kommoden\}

v. $\quad$ støvede, af, han, kommoden\}

vi. \{støvede, af, han, kommoden\}

$\begin{array}{lll}\rightarrow & \text { a. } & \\ \rightarrow & \text { b. } & \text { kan støvede kommoden af } \\ \rightarrow & \text { c. } & \text { *af støvede han kommoden } \\ & & \text { etc. } \\ \rightarrow & \text { a. } & \text { han støvede kommoden } \\ \rightarrow & \text { b. } & \text { *støvede kommoden han } \\ & & \text { etc. } \\ \rightarrow & \text { a. } & \text { kommoden støvede } \\ \rightarrow & \text { b. } & \text { støvede kommoden } \\ \rightarrow & \text { a. } & \text { han støvede } \\ \rightarrow & \text { b. } & \text { støvede han } \\ \rightarrow & \text { a. } & \text { han støvede af } \\ \rightarrow & \text { b. } & \text { *af støvede han } \\ \rightarrow & \text { a. } & \text { *af støvede } \\ \rightarrow & \text { b. } & \text { *støvede af }\end{array}$


Med udgangspunkt i $\mathrm{D}_{\text {støvede }}$ under (i) fremgår det at ingen af konstituenterne er obligatoriske i absolut forstand - men at konsekvenserne ved at slette dem er forskellige. Tre forhold er væsentlige. Grammatiske sætninger med og uden [af] fører til konstruktion af forskellige $1^{\circ}$-repræsentationer $(\mathrm{i} \neq \mathrm{ii} ; \mathrm{iv} \neq \mathrm{v}$ ); i grammatiske sætninger med kun én konstituent i domænet kan det ikke være $[a f]$ (iii, iv $\neq$ vi); sætninger med $[a f]$ kan være grammatiske med enten to eller tre konstituenter i domænet, men i begge tilfælde fører de til konstruktion af samme $1^{\circ}$-repræsentation $(\mathrm{i}=\mathrm{v})$.

Sammenligner man dette med domænet bag (16c) vil der vise sig flere diagnostistiske forskelle:

$\begin{array}{llll}\text { i. }\{\text { smadrede, han, kommoden\} } & \rightarrow & \text { a. } & \text { han smadrede kommoden } \\ & \rightarrow & \text { b. } & \text { kommoden smadrede han } \\ \text { ii. }\{\text { smadrede,han, kommoden\} } & \rightarrow & \text { a. } & \text { kommoden smadrede } \\ \text { iii. }\{\text { smadrede,han, kommoden\} } & \rightarrow & \text { a. } & \text { ?han smadrede }\end{array}$

Her er [kommoden] som eneste konstituent obligatorisk, og det er den samme $1^{\circ}$ repræsentation der konstrueres fra både (i) og (ii). Disse forskelle træder yderligere frem hvis vi betragter v's diateseform som vilkårlig, således at passiv i denne forbindelse blot er en konstituentreducerende operation:

20a) Der blev støvet af

20b) Der blev støvet

20c) * Der blev smadret

20d) Der blev smadret kommode/kommoder

Her er $1^{\circ}$-repræsentationen konstrueret fra (a) forskellig fra den der konstrueres fra (b). Der kan ikke konstrueres én fra (c), med mindre den obligatoriske konstituent bevares, dog - og det er væsentligt (se nedenfor) - i non-argumentativ form.

Ser vi til sidst på (16b) og (16d) er det klart at hverken kategori eller tematisk rolle er afgørende for forskellen i obligatorisk tilstedeværelse af konstituenten [hele natten]. Den forskel betragtes sædvanligvis som en forskel imellem s y $\mathrm{n}$ t a k t i s ke funktioner. I (16b) er [hele natten] et komplement, i (16d) et adjunkt. ${ }^{15}$ Det er ganske på sin plads, for der er ikke nogen grund til at anse dem for konstruktionsmæs sigt forskellige.

Det billede der tegner sig fra et fortolkningsperspektiv er en inddeling i fire konstituenttyper, hvoraf to kan, to ikke kan, fungere som subjekt og objekt, uanset deres lineære position, og hvoraf to leverer, to ikke leverer, fundamental information til konstruktion af a rten af $2^{\circ}$-repræsentation. Dette er i alt væsentligt hvad Austins (og Barwise/Perrys) situationstyper er: forskellige slag s $2^{\circ}$-repræsentationer. Vi får en systematik som i (21), hvor [ $\left.\pm_{\mathrm{ARG}}\right]$ karakteriserer konstituenter der er valgbare som subjekt/objekt, mens $\left[_{\textrm{OBL}}\right]$ markerer konstituenter der bærer typologisk fortolknings- 
information:

21)

\begin{tabular}{|c|c|c|}
\hline & +ARG & -ARG \\
\hline +OBL & Komplement & Parasit \\
\hline -OBL & Argument & Satellit \\
\hline
\end{tabular}

'Komplement' og 'argument' er veltjente termer hvis indhold ikke er uforeneligt med deres anvendelse her, selvom den første sædvanligvis er en syntaktisk, den anden en semantisk term. De er begge argumentative, bærer information til identifikation af entiteter i diskursuniverset, og er typisk realiseret ved DP. 'Satellit' bruges f. eks. i Diks (1989) version af funktionel grammatik, i en betydning meget tæt på anvendelsen her. 'Parasit', derimod, er mig bekendt ikke en etableret grammatisk term. Den betegner non-argumentative konstituenter hvis tilstedeværelse på den ene side er dikteret af det grammatiske system, på den anden af det semantiske system, hvor de bærer information til diskrimination af $2^{\circ}$-repræsentationer. De vil i sprog som dansk typisk indgå i nominaliseringer af de verber der selekterer dem, så vi har nominaliseringer som

22) afstøvning (af papiruld - www.sbi.dk/forskning/alternativ_isolering/ resumeer/ afstoevning.htm)

Mange vil sandsynligvis hævde, at [af] ikke er en selvstændig konstituent, men tværtimod en del af et (komplekst) leksikalie, [støve _-_ af], og at vi derfor i bedste fald har at gøre med grænsefladen imellem morfologi og syntaks. Vi ville dermed have forskellige leksikalier, mindst [støve__op], [støve___til], [støve__igennem], allesammen transitiverende afledninger af intransitivt [støve]. Dette støttes af at de optræder som sammensatte (transitive) verber, [opstøve], [(i)gennemstøve], [tilstøve], [afstøve]. Det er naturligvis uomtvisteligt - men også fordomsfuldt. Pointen her er at partiklen, når den er skilt fra sin verbalstamme, er obligatorisk, og at den er det netop på grund af sin konstruktionssemantiske effekt.

Jeg betragter imidlertid en lang række andre konstituenter som parasitter, eksempelvis visse forekomster af refleksive og reciprokke pronominer, inkorporerede NPer, prædikative AP/NPer, samt obligatoriske adverbier af forskellig art. Fælles for dem er deres nonargumentative status og manges evne til at indgå som førsteled i sammensætninger som f. eks.

\footnotetext{
23a) selvpromovering ( $\leftarrow$ promovere (sig) selv)

23b) kommodesmadring $(\leftarrow$ smadre kommode $(r))$

23c) rødmalet $(\leftarrow$ male (noget) rødt)

23d) herboende $(\leftarrow$ bo her $)$
}

Det inkorporerende eksempel (23b) er suggestivt. Det blev bemærket i forbindelse med (20d) at obligatoriske konstituenter kun kunne optræde i upersonlige kontekster i ikkeargumentativ form. Under aktuelle antagelser forklares dette forhold ved at [kommode $(r)]$ 
ikke (længere) er et komplement, men er 'reduceret' til en parasit. ${ }^{16}$

Den væsentligste hensigt med at opstille denne - mange vil sikkert mene redundante - taksonomi over konstituenttyper er at forsøge at godtgøre at argumentstruktur er 'værdifri' i forhold til kategoriale og funktionsmæssige hensyn. Hvis jeg skulle opsummere det sagte på en måde der er sammenlignelig med illustationen af GB/PPs informationslag i (17) kunne det se således ud:

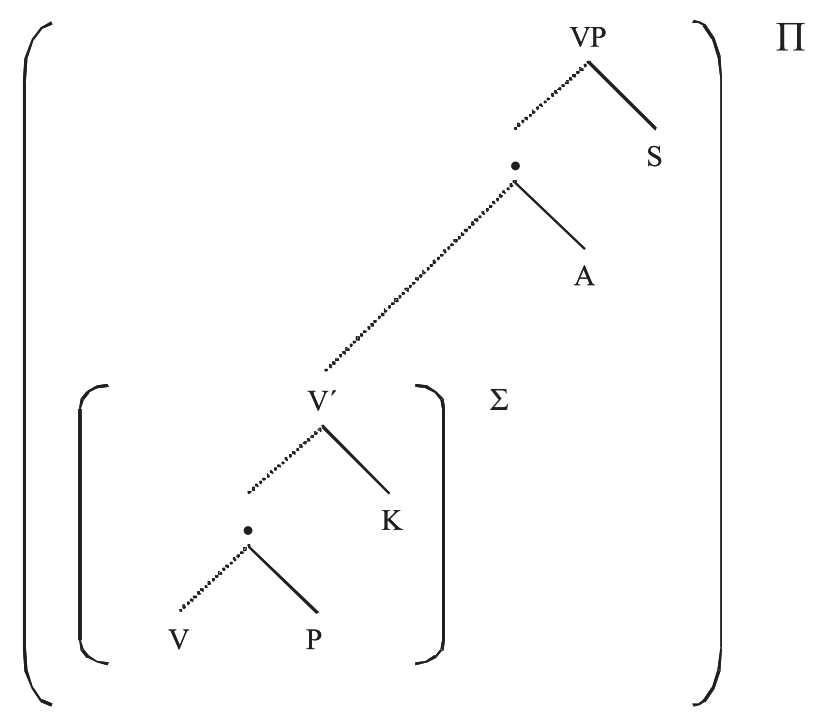

Det nederste 'lag', V', dominerer det leksikalske verbum plus dets selekterede konstituenttyper, komplement og parasit. Det bærer information til konstruktion af en $2^{\circ}$-repræsentation af type $\Sigma$. Dot-notationen er afbigt for bijektionsprincippet - både $\mathrm{K}$ og P er søstre til $\mathrm{V}^{17}$. Det øverste lag, VP, dominerer $\mathrm{V}^{\prime}$, der - i overensstemmelse med gængse generative antagelser - selekterer argumenter og satellitter. VP leverer dermed information til dannelse af $2^{\circ}$-repræsentationen $\Pi$, hvor $\Pi$ er valgt som signatur fordi denne repræsentation er konstrueret på basis af sprogligt materiale som i logisk sammenhæng ville udgøre en proposition. (24) er dermed ment som en notation for ren a r g u m e n t stru kt u r. Den er udelukkende hierarkisk, og der er ikke foretaget hverken kategoriale eller funktionelle tilskrivninger til P, K, A, eller S.

Der er derimod foretaget en tilskrivning der minder om Andersons basale kasusrelationer fra fig. 4 ovenfor, om end på tentativt og m e get abstrakt lokalistisk grundlag: 


\begin{tabular}{|l|c|c|c|c|}
\hline konstituenttype & $\mathrm{P}$ & $\mathrm{K}$ & $\mathrm{A}$ & $\mathrm{S}$ \\
\hline \multirow{2}{*}{ SELEKTIONSKOMPONENTER } & & & SOURCE & SOURCE \\
\cline { 2 - 5 } & & GOAL & & GOAL \\
\hline
\end{tabular}

$\mathrm{P}=$ parasit $; \mathrm{K}=$ komplement; $\mathrm{A}=$ argument; $\mathrm{S}=$ satellit

Fig. 5: Tentativ semantisk karakteristik af konstituenttyper

Af de to obligatoriske konstituenttyper, $\mathrm{P}$ og $\mathrm{K}$, er P den semantisk neutrale, hvis eneste konstruktionsmæssige effekt er at diskriminere imellem $2^{\circ}$-repræsentationer. Han støver af overfor han støver rummer begge information til konstruktion af repræsentationer der sætter diskursreferenten for han i relation til en foregang der involverer støv, men begge digitaliserer komplet al information om evt. andre aktanter. Ikke desto mindre har de forskellige sandhedsbetingelser, hvilket i denne kontekst svarer til at sige at der er tale om to distinkte repræsentationstyper. Udover at være bestemmende for repræsentationstype bidrager $\mathrm{K}$ derimod også med information til identifikation af involverede aktanter. Derfor betragtes i (23b) kommode- i kommodesmadring som et 'reduceret' K. Komplementer er GOAL for repræsentationens foregang, på samme måde som argumenter er dens SOURCE. Satellitter bidrager typisk med information til skabelse af baggrund for foregange, under alle former for lokaliseringer, i sted som i tid og måde. Hvorvidt de kan subsumeres under notationen [SOURCE, GOAL] er en anden sag. Men alt dette må underkastes nærmere empirisk prøvelse.

\section{VIDERE PERSPEKTIVER}

Diskussionen i afsnit 4-5 har været koncentreret om hvilke minimale krav man ud fra et fortolkningsmæssigt synspunkt kan stille til beskrivelsen af det informationslag i (17) der drejer sig om argumentstruktur. Hvis det er rigtigt at output fra den fortolkningsprocessor der aktiveres af denne type information er strengt hierarkisk og blot benytter sig af information båret af de sproglige elementer der i logisk-semantisk forstand udgør en proposition (som antaget), udestår der en redegørelse for anvendelsen af den information der falder under de to øvrige kategoriseringer, hhv. informationsstruktur og modaliseringsstruktur. Omtalen af hver af dem vil være koncentreret om at karakterisere deres funktion samt at sætte dem i relation til deres interaktion med repræsentationen af argumentstruktur i (24), herunder spørgsmålet om subjekt/objektvalg.

\subsection{Informationsstruktur}

Modulet til håndtering af informationsstruktur (IS) er i alt væsentligt et lineariseringsmodul der fastlægger ikke-verbale konstituenters indbyrdes rækkefølge under hensyn til (sprogspecifikke) principper for topikalisering, fokusering, tunge og lette led, 'scrambling', etc. Syntaktiske processer som subjekt/objektvalg, sætningskløvning, pseudokløvning, parallelkonstruktion (Koster 2000) og ekstrapolering, prosodiske principper for fokusering og emfase ses med andre ord som processer der med en argument- 
struktur som input leverer en 1 i n e a r i s e r e t struktur som output. Om dette sker serielt eller parallelt er imidlertid et problematisk spørgsmål. Set fra et fortolkningsmæssigt synspunkt er der argumenter for parallelprocessering (jv. 'garden-path' sætninger igen), mens det fra et produktionsmæssigt synspunkt er nemmere at argumentere for seriel processering, med П som input til IS.

Alt $\mathrm{i}$ alt er min opfattelse af informationsstruktur sammenfaldende med Lambrechts (1994: 5) karakteristik:

\begin{abstract}
INFORMATION STRUCtURE: That component of sentence grammar in which propositions as conceptual representations of states of affairs are paired with lexicogrammatical structure in accordance with the mental states of interlocutors which use and interpret these structures as units of information in given discourse contexts. [Min fremhævning - tt]
\end{abstract}

GB/PPs flytningstransformationer (Head-Movement, NP-movement, $W h$-movement) og minimalismens åbne ('overt') og skjulte ('covert') flytninger tjener alle det ene formål at forklare det, iflg. Chomsky, simple, åbenlyse og universelle faktum at sprog i det store flertal af sætninger fremviser eksempler på konstituenter der optræder lineært adskilt fra konstituenter de fortolkes sammen med, og som de derfor formodes at stå i lokalt, hierarkisk forhold til. ${ }^{18}$ Det er naturligvis klart at disse forhold skal belyses, men det er fortsat ikke bevist, hverken eksperimentelt eller matematisk, at flytningsmetaforen er den eneste brugbare til det formål.

Uanset hvordan det belyses er det et anliggende for IS som her forstået. Ét af de forhold der skal belyses er indgangsspørgsmålet om valg af subjekt og objekt, der nu kan diskuteres i rette kontekst. Sprog som dansk og engelsk - i modsætning til italiensk og spansk, for eksempel - betragtes som subjektskrævende sprog. I (GB/)PP regi gøres denne sprogtypologiske forskel til et anliggende for forskellige parameterindstillinger i de to sprogtyper. Der antages at være en universel subjektsparameter, hvis indstilling til plus eller minus er relateret til verbalmorfologi.

Subjekter er som bekendt ikke absolut obligatoriske i dansk og engelsk - ellers skulle vi have haft ét i Mary is easy [subjekt] to please. Og vi skulle have haft et i [subjekt] skrub af! Subjekter er kun obligatoriske i finite sætninger, ikke i non-finite eller a-finite (imperativiske). Det hænger fint sammen med argumentet fra verbalmorfologi. Det betyder samtidig at subjekter kun er obligatoriske $\mathrm{i}$ - og definerende for en bestemt type af - sæt n in g s s tr u k t u r e r. Objekter, derimod, er obligatoriske - og definerende - for bestemte typer af verber. I kasus- og funktionsgrammatiske fremstillinger ses valg af subjekt/objekt ofte som en funktion af 'animateness' hierarkiet, der kan have denne udformning (Dowty 1991: 578): 


$$
\text { AGENT }>\left\{\begin{array}{l}
\text { INSTRUMENT } \\
\text { EXPERIENCER }
\end{array}\right\}>\text { PATIENT }>\left\{\begin{array}{l}
\text { SOURCE } \\
\text { GOAL }
\end{array}\right\}
$$

- hvor '>' betyder 'har forrang som subjekt/objekt/oblik'. Endnu engang gælder generaliseringen kun en særlig slags sætningsstrukturer, denne gang strukturen bag a ktive finite sætninger. Passive sætninger er karakteriseret ved at AGENS - hvis udtrykt - optræder syntaktisk som oblik. Dowty bemærker da også at ordningen i (25) blot er den 'sædvanlige'.

Der er en forskel imellem subjektskrævende sprog som dansk og tysk på den ene side, engelsk på den anden, med hensyn til hvor langt konstituentreduktion tillades. Dansk og tysk har maksimalt konstituentreducerede upersonlige sætninger som Der blev danset. Det tillader engelsk ikke. Dette kan formuleres som et definerende princip for engelsk:

ARG-PRINCIPPET

Engelsk tillader ikke konstituentreduktion af samtlige argumentative konstituenter i en sætningsstruktur.

Det betyder naturligvis ikke at engelsk ikke kan have verber der selektio n s mæs sig t er argumentløse, som f. eks. 'weather-verbs'.

Mere interessant er det at bestemmelsen af argumentstruktur hermed er gjort uafhængig af subjekt/objektvalg. Argumentstruktur fastlægges af leksikalske verbers selektionspotentiale. Den falder i to dele, hvor de obligatoriske konstituenter sammen med v fastlægger typen af $2^{\circ}$-repræsentation, $\Sigma$, mens de fakultative konstituenter sammen med $\Sigma$ fastlægger det propositionelle indhold, П. Men subjekt/objektvalg er ikke isomorft med fakultativitet. Blandt traditionelt 'transitive' verber i engelsk finder vi fire basale og velkendte typer mht argumentselektion, baseret på trækkene [ \pm KAUSATIV, \pm REFLEKSIV]:

26)

i. a. He landed

A

ii. a. He ate

$\mathrm{C}$

iii. a. He drowned

A

iv. a. He washed

$\mathrm{C}$

$$
\text { it } \rightarrow \text { b. He landed }
$$

c. It landed

$\mathrm{A}=$ [+KAUSATIV, -REFLEKSIV]

it $\rightarrow$ b. He ate c. -

$\mathrm{A}=$ [-KAUSATIV, -REFLEKSIV $]$
it $\rightarrow$ b. -
c. It drowned

$\mathrm{C}=$ [+KaUsativ, +REFLEKSIV]

it $\rightarrow$ b. - c. -

$\mathrm{C}=$ [-KaUSATIV, +REFLESKSIV $]$

Pilene markerer at (b) og (c) eksemplerne - hvor de forekommer - fører til konstruktionen 
af samme П som (a) eksemplerne ved konstituentreduktion. Jeg vil ikke her gå dybere ind i en diskussion af disse forhold, blot pege på et enkelt bemærkelsesværdigt fænomen i forhold til CA og CC verber. Både [eat] og [wash] optræder blandt de 28 engelske verber Jespersen udnævner til at have udviklet en 'passiv' betydning af deres 'aktive' former, som i standardeksemplet the book sells well (eksemplerne fra Jespersen 1927: 348f):

27a) cut out the rotten from your apple, your apple eats the better

27b) It is only cotton, and washes better than any other colour

Denne konstruktionstype breder sig og diskuteres nu under termen 'middle'. Det er et karakteristisk træk ved den at der indgår et adverbielt led, selvom det ikke af alle anses for obligatorisk (se f. eks. Iwata 1999). Men det er det sandelig, hvis der ikke er anden (kontekstafhængig eller prosodisk) information til fastlæggelse af argumentstruktur. Adverbialet selekteres som en parasit, og realiserer dermed materielt den obligatoriske konstituent der ellers ville være urealiseret. Hvilke typer af konstituenter forskellige leksikalske verber selekterer, og hvordan konstituenterne C og A fordeler sig som hhv. subjekt og objekt, er empiriske spørgsmål som jeg må lade ligge her.

\subsection{Modaliseringsstruktur}

Henvisningen til "in given discourse contexts" i citatet fra Lambrecht ovenfor kan tjene som introduktion til dette afsnit, for det er netop hvad modalisering drejer sig om: tøjringen af en propositionel struktur som (24) til en diskurskontekst. Modaliseringsstrukturlaget (MS) rummer information dels til fastlæggelse af den tidslige og rumlige organisation af $2^{\circ}$-repræsentationer i forhold til andre (tempus og modalitet), dels om den interne temporale og lokativiske profil af de foregange der konstituerer repræsentationen (aspekt og aktionsart). ${ }^{19,20}$ Der er meget strenge begrænsninger på den indbyrdes 1 i n e a r i t e $t$ imellem tekstlige forekomster af materielt realiserede medlemmer af disse kategorier, men de har derudover ikke nogen iøjnefaldende sammenhæng med hierarkisk strukture ring. Det spiller ikke den store empiriske rolle om vi noterer dem (for engelsk) i abstrakt form som (28a) eller (28b) (som egenskab ved leksikalsk V er aktionsart ikke medtaget):

28a) Tempus - Modalitet - Perfektum - Progressiv - (Diatese)

28b) Tempus

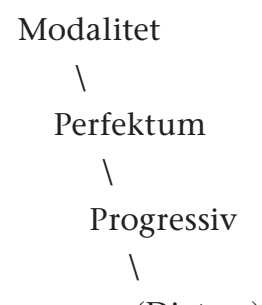

(Diatese) 
Derimod etablerer de en matrix, et abstrakt rum til forankring af $\Pi$ omkring ytringssituationen, den situation der skabes $\mathrm{i}$ og med at nogen siger noget. Ytringssituationen etablerer en $1^{\circ}$-repræsentation af sig selv i forhold til hvilken $2^{\circ}$-repræsentationer organiseres, og har som fast inventar et deiktisk centrum (locus for taler), et orienteringspunkt (locus for tiltalte), og en afgrænsning, fysisk markeret ved talevolumen (Thrane 1980: 194). Billedet ser således ud (jf. Thrane 1983: 193):

29)

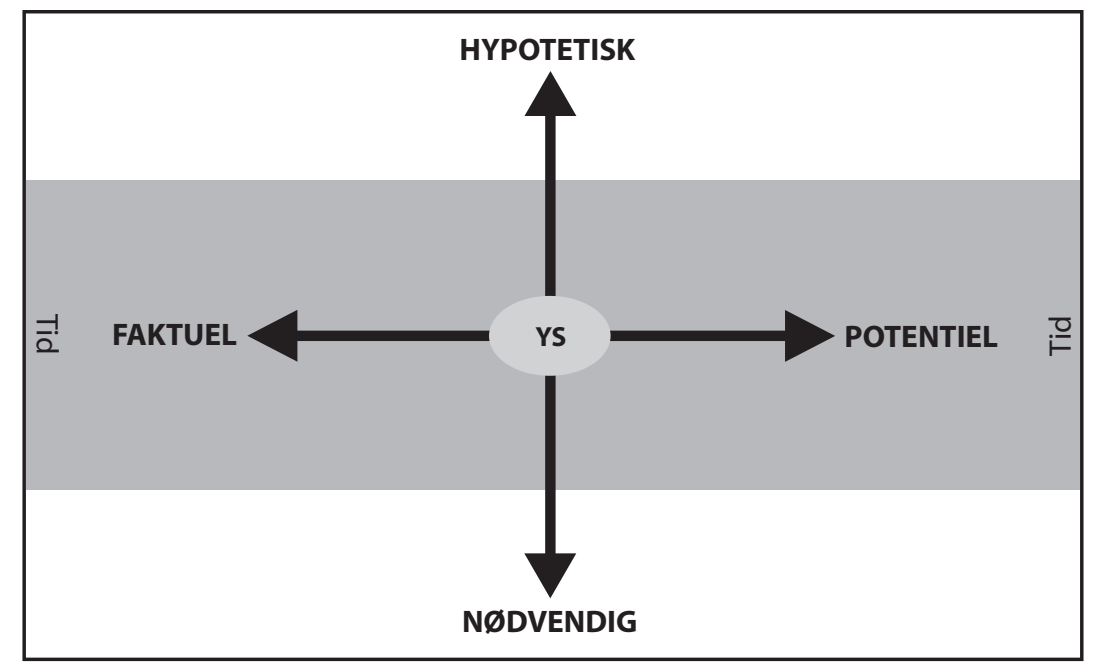

Tempus- og (epistemisk fortolkede) modalmarkører (typisk i form af verbalkategorier og adverbier) bærer information om 'placeringen' af $\Pi$ i forhold til YS langs en FAKTUELPOTENTIEL akse og en HYPOTETISK-NøDVENDIG akse, hvoraf den sidste rækker uden for tid - til akkomodering af hhv. 'mulige verdener' og logisk-matematiske sandheder. Deontiske fortolkninger af modalmarkører baserer sig tillige på forudsat eller implicit information i YS om autoriteter og deres legitimitet. Aspektmarkører bærer information om profilen af $\Pi_{i}$ i forhold til $\Pi_{j}$, der igen forudsat eller implicit etablerer et referencepunkt. Det er således muligt at betragte fortolkningsmatricen som en formalisering af Reichenbachs (1947) fortolkningsmodel for tempus/aspekt-markører, generaliseret til også at omfatte modalitet.

Det fremgår at jeg betragter $\Pi$ - dvs. strukturer som (24) - som input til MS. Hvis vi samtidig tager hensyn til diskussionen i 6.1. fører det til en reorganisering af de tre moduler i (17) som vist her: 
30)

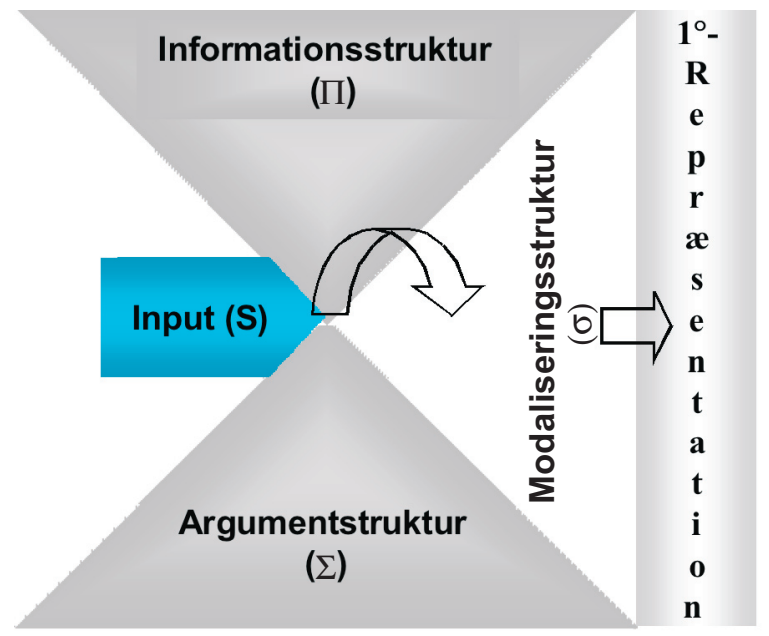

Input $\mathrm{S}$ behandles - serielt eller parallelt - af moduler til fastlæggelse af argumentog informationsstruktur der leverer en propositionelt baseret $2^{\circ}$-repræsentation, $\Pi$, til modaliseringsstrukturmodulet. Det indplacerer $\Pi$ i en matrix i forhold til en default $1^{\circ}$-repræsentation af ytringssituationen. $\Pi$ tøjres $i$ tid og rum og konverteres dermed til en $2^{\circ}$-repræsentation, $\sigma$. Denne rummer nu, i komplet digitaliseret form, den fornødne information til konstruktion af en leksikalsk afledt $1^{\circ}$-repræsentation, dvs. en repræsentation vi kan sætte i relation til andre (aktive) $1^{\circ}$-repræsentationer med den abstrakte repræsentation af ytringssituationen som udgangspunkt. Jeg ser således ytringssituationen som den grænseflade hvor konverteringen fra $2^{\circ}$ - til $1^{\circ}$ repræsentation foregår. Hver ytringssituation er i sig selv en historisk situation (i Austins terminologi). Men den abstrakte repræsentation af den er en situationst y pe hvis konstituerende elementer 'nulstilles' fra én ytringssituation til den næste. Det er ytringssituationen som abstrakt $1^{\circ}$-repræsentation der er forudsætningen for konverteringen af $2^{\circ}$-repræsentationer til $1^{\circ}$-repræsentationer.

\section{LITTERATUR}

Allerton, David J. (1982), Valency and the English Verb, London: Academic Press.

Anderson, John M. (1971), The Grammar of Case, Cambridge: Cambridge University Press.

Anderson, John M. (1977), On Case Grammar, London: Croom Helm.

Anderson, John M. (1997), A Notional Theory of Syntactic Categories, Cambridge: Cambridge University Press.

Austin, John L. (1950), “Truth”, in: Austin, John L. (1970), Philosophical Papers, London: Methuen, pp. 117-133.

Barwise, Jon, John Perry (1983), Situations and Attitudes, Cambridge/Mass.: Bradford. 
Thrane, Hvorfor er sproget så svært at forstå?

Bech, Gunnar (1955/1957), Studien über das deutsche Verbum infinitum, 1+2, København: Det Kgl. Danske Videnskabernes Selskab (= Historisk-filologiske Meddelelser, vol. $35 / 2$ og 36/6).

Bickerton, Derek (1995), Language and human behavior, Seattle: University of Washington Press.

Bohn, Ocke-Schwen (2000), "Linguistic relativity in speech perception: An overview of the influence of language experience on the perception of speech sounds from infancy to adulthood", in: Niemeier, S., René Dirven (eds.) (2000), Evidence for Linguistic Relativity, Amsterdam, Philadelphia: J. Benjamins, pp. 1-28.

Bouchard, Denis (1995), The Semantics of Syntax. A Minimalist Approach to Grammar, Chicago: University of Chicago Press.

Chomsky, Noam (1981), Lectures on Government and Binding. The Pisa Lectures, Dordrecht: Foris Publications.

Chomsky, Noam (1986), Knowledge of Language: Its Nature, Origin, and Use, New York: Praeger.

Chomsky, Noam (2000), The Architecture of Language. The Delhi Lectures, January 1996, New Delhi: Oxford University Press.

Dalrymple, Mary, Tracy Holloway King (2000), Missing-Object Constructions: Lexical and Constructional Variation, Berkeley, University of California: CSLI Publications (The LFG00 Conference).

Dik, Simon C. (1989), The Theory of Functional Grammar, Part I, The Structure of the Clause, Dordrecht: Foris Publications.

Dowty, David (1991), "Thematic Proto-Roles and Argument Selection", Language 67/3 (1989), pp. 547-619.

Dretske, Fred I. (1981), Knowledge and the Flow of Information, Oxford: Blackwell.

Dretske, Fred I. (1995), Naturalizing the Mind, Cambridge/Mass.: MIT.

Fillmore, Charles J. (1968), "The Case for Case", in: Bach, Emmon, Robert T. Harms (eds.) (1968), Universals in Linguistic Theory, New York: Holt, Rhinehart \& Winston, pp. 188.

Fillmore, Charles J. (1977), "The Case for Case Reopened", in: Cole, Peter, Jerrold M. Sadock (eds.) (1977), Syntax and Semantics, Vol. 8, New York: Academic Press, pp. 59-81.

Gazdar, G., E. Klein, G. Pullum, I. Sag (1985), Generalized Phrase Structure Grammar, Oxford: Blackwell.

Goodman, Nelson (1976), Languages of Art, Indianapolis: Hackett.

Gruber, Jeffrey S. (1965), Studies in Lexical Relations, Department of Linguistics and Philosophy: MIT (Ph. D.-thesis).

Hicks, Glyn (2003), "So Easy to Look At, So Hard to Define". Tough Movement in the Minimalist Framework, University of York, Department of Language \& Linguistic Science (MA-thesis).

Hornstein, Norbert (1999), "Movement and Control", Linguistic Inquiry, $30 / 1$ (1999), pp. 69-96.

Iwata, Seizi (1999), "On the status of an implicit arguments in middles [sic]", Journal of Linguistics, 35 (1999), pp. 527-553.

Jackendoff, Ray S. (1983), Semantics and Cognition, Cambridge/Mass.: MIT (2. ed. 1986). Jackendoff, Ray S. (1987), "The status of thematic relations in linguistic theory", Linguistic Inquiry, 18 (1987), pp. 369-411. 
Thrane, Hvorfor er sproget så svært at forstå?

Jackendoff, Ray S. (1997), The Architecture of the Language Faculty, Cambridge/Mass.: MIT.

Jespersen, Otto (1927), A Modern English Grammar on Historical Principles, Part III, Syntax, Vol. 2, London: Allen \& Unwin (1965).

Jones, Michael A. (1983), "Getting 'tough' with Wh-movement", Journal of Linguistics, 19 (1983), pp. 129-59.

Kamp, Hans, Uwe Reyle (1993), From Discourse to Logic. Introduction to Modeltheoretic Semantics of Natural Language, Formal Logic and Discourse Representation Theory, I + II, Dordrecht: Kluwer.

Karttunen, Lauri (1976), "Discourse referents", in: McCawley, James D. (ed.) (1976), Notes from the linguistic underground. Syntax and Semantics, Vol. 7, New York: Academic Press, pp. 363-85.

Kornai, András, Geoffrey K. Pullum (1989), The X-bar Theory of Phrase Structure, Palo Alto: CSLI-publications.

Koster, Jan (2000), Extraposition as Parallel Construal, PDF-file. http://odur.let.rug.nl/ $\sim$ koster/papers/parallel.pdf.

Lambrecht, Knud (1994), Information structure and sentence form, Cambridge: Cambridge University Press.

Lasnik, Howard (2001), "Derivation and representation", in: Baltin, Mark, Chris Collins (eds.) (2001), The Handbook of Contemporary Syntactic Theory, Oxford: Blackwell (2003), pp. 62-88.

Mohanan, K. P. (1983), "Functional and anaphoric control", Linguistic Inquiry, 14/4 (1983), pp. 641-674.

Nanni, Deborah L. (1980), "On the surface syntax of constructions with easy-type adjectives", Language, 56/3 (1980), pp. 568-581.

Parsons, Terence (1995), "Thematic Relations and Arguments", Linguistic Inquiry, 26/4 (1995), pp. 635-662.

Pinker, Steven (1995), The Language Instinct. The New Science of Language and Mind, London: Penguin Books.

Pollard, Carl, Ivan A. Sag (1994), Head-Driven Phrase Structure Grammar, Menlo Park: The University of Chicago Press.

Postal, Paul (1971), Cross-Over Phenomena, New York: Holt, Rhinehart and Winston.

Postal, Paul (2003), “'(Virtually), conceptually necessary'”, Journal of Linguistics, 39/4 (2003), pp. 599-620.

Pustejovsky, James (1995), The Generative Lexicon, Cambridge/Mass.: MIT.

Quirk, Randolph, Sidney Greenbaum, Geoffrey Leech, Jan Svartvik (1972), A Grammar of Contemporary English, London: Longman.

Reichenbach, Hans (1947), Elements of Symbolic Logic, New York: Free Press (1966).

Schøsler, Lene, Mary Talbot (eds.) (1995-98), Studies in valency, Odense: Odense University Press (RASK Supplement, 1, 5, 7, 8).

Strawson, P. F. (1965), "Truth", in: Strawson, P. F. (1965), Logico-Linguistic Papers, London: Methuen (1971), pp. 190-213.

Tesnière, Lucien (1959), Éléments de syntaxe structurale, Paris: Klincksieck.

Thrane, Torben (1980), Referential-semantic analysis, Cambridge: Cambridge University Press. 
Thrane, Hvorfor er sproget så svært at forstå?

Thrane, Torben (1983), "On the universality of AUX", Acta Linguistica Hafniensia, 18/2 (1983), pp. 154-200.

Thrane, Torben (1992), "The Fallacy of Descriptivism", in: Hansen, Steffen Leo, Finn Sørensen (eds.) (1992), Topics in Semantic Interpretation, København: Samfundslitteratur, pp. 103-148.

Thrane, Torben (1997), "Understanding semantics", in: Bache, Carl, Alex Klinge (eds.) (1997), Sounds, Structures and Senses: Essays presented to Niels Davidsen-Nielsen on the Occasion of his Sixtieth Birthday, Odense: Odense University Press, pp. 235- 250.

Thrane, Torben (1998), "Nominaler, nominaliseringer og semantisk kompleksitet", Hermes, 21 (1998), pp. 39-66.

Thrane, Torben (1999), "Hvorfor kan det transitive subjekt ikke indgå som førsteelement i et dansk sammensat substantiv med verbalafledt kerne?", i: Harder, Peter (red.) (1999), Funktionelle fodnoter. Formel sprogteori: Nogle udfordringer til den funktionelle tilgang, København: Københavns Universitet, pp. 66-81.

Thrane, Torben (in press), “Representing Interpreters' Knowledge: Why, What, and How?", to appear in: Dam, Helle, Jan Engberg, Heidrun Gerzymisch-Arbogast (eds.), Knowledge Systems in Text and Translation, Berlin: Mouton de Gruyter.

Togeby, Ole (2003), Fungerer denne saetning? Funktionel dansk sprogloere, København: Gads Forlag.

Wright, Larry (1976), Teleological Explanations, Berkeley: University of California Press.

\section{NOTER}

1 Artiklen er en revideret og væsentligt udvidet udgave af et oplæg på Statsbiblioteket i Århus den 27.11.2003 inden for rammerne af det Fjerde Forskningskollokvium Sprog med titlen Syntaks og Betydning. Jeg vil gerne benytte lejligheden til at takke symposiets initiativtager og primus motor, Volkmar Engerer, for invitationen til at deltage; samt deltagerne for kritiske kommentarer.

2 Tilhørere med god hukommelse vil erindre at dette også var i fokus for mit oplæg ved symposiet omtalt i note 1 . De vil derimod nok finde at det jeg skriver om her er noget andet end det jeg sagde. Det jeg skriver om her udgør snarere grundlaget for at diskutere det jeg sagde. Det udgør det fortolkningsrelevante indhold af begrebet "argumentstruktur".

3 Dretskes (1981: 183ff) beskrivelse af komplet digitaliseret information er anderledes - men også temmelig uigennemskuelig, og den gentages ikke i senere arbejder.

4 I en kritisk, men meget underholdende, artikel benytter Paul Postal (2003) samme teknik i sin argumentation mod væsentlige antagelser i det generative standardparadigme.

5 Årsagen til og omfanget af denne degeneration er ikke endelig fastslået, men er genstand for megen aktiv forskning. Se f. eks. Bohn (2000) og senere arbejder.

6 Der er så vidt jeg kan se én, måske to, undtagelser fra denne generelle påstand. Hans Kamp \& Uwe Reyles (1993) teori om diskursrepræsentation forudsætter en generativ beskrivelse af morfosyntaktisk struktur som udgangspunkt for den modelteoretiske konstruktionen af diskursrepræsentationsskemaer; og Denis Bouchard (1995) påberåber sig på minimalistisk grundlag ligeledes en generativ basis for fortolkningen af argumentstruktur. Det er dog kun Kamp \& Reyle der formulerer egentlige regler for repræsentationskonstruktion.

7 Det vil føre for vidt i denne artikel at diskutere forholdet imellem notationsystemer og repræsentation. Jeg tillader mig derfor blot at stipulere at et notationssystem er den fysiske implementering af et designet $2^{\circ}$-repræsentationssystem. De repræsentationsformer der omtales i dette afsnit er således alle notationssystemer designet til at repræsentere sprogstruktur. Den videnskabsteoretiske holdning bag denne påstand er dybest set instrumentalistisk, idet 
den blot betragter notationssystemer som praktiske redskaber til eksplicitering af iagttagne regelmæssigheder uden at tillægge dem nogen form for psykologisk realitet, lige så lidt som trykmåleren beskrevet i afsnit 2 ovenfor kan tillægges nogen form for fysisk-molekulær realitet om hvad der egentlig foregår inden i beholderen som den bærer information om. Se i øvrigt Nelson Goodman (1976: ch. IV) for en detaljeret redegørelse for notationssystemer.

8 Dette er naturligvis ikke nogen ny erkendelse. Det bedst artikulerede argument imod det 'rigide' leksikon er formentlig Pustejovsky (1995).

9 Se Thrane (1997) for en nærmere redegørelse for den position leksikalsk betydning formodes at have i informationsstrømmen.

10 PRO er i GB/PP-traditionen standard som leksikalsk markør for det tomme subjekt for infinitiven/gerundiet i kontrol-strukturer; se Hornstein (1999) for udførlig diskussion af dets teoretiske status.

11 Dertil kommer naturligvis alle de forskellige tilfælde af kontekstafhængige gaps og ellipser, som ikke på dette tidspunkt spiller nogen afgørende rolle.

12 Dette er ment som en noget håndfast beskrivelse af det teoretiske skel imellem en deriva tionel og en repræsentation el grammatik. Se Lasnik (2001) for en lidt mere nuanceret diskussion, hvis konklusion er at selv tilsyneladende klart repræsentationelle fænomener 'er forenelige' med et derivationelt synspunkt.

13 'Sanddruhed' er et temmelig komplekst begreb hvis bestemmelse undertiden fører til filosofisk relativisme. Den diskussion falder uden for rammerne af denne artikel. Jeg henholder mig til den dagligdags opfattelse hvorefter der er en påviselig forskel imellem at ly ve og at ta le sandt.

14 Proceduren er inspireret af Gunnar Bechs (1955/57) 'division' af tyske verbalsyntagmer med forskellige hjælpeverber - men parallellen skal dog ikke strækkes for vidt.

15 Især i den britiske tradition er den terminologiske uklarhed fremherskende. I (16b) siges [hele natten] at have funktionen 'adverbial complement' (dvs. valgfrit obligatorisk!), mens det i (16d) har funktionen 'adjunct' , der er en underfunktion til 'adverbial' (Quirk et al. 1972).

16 Se Thrane (1999) for nærmere diskussion af denne type nominaliseringer; generelt om nominalisering se Thrane (1998).

17 Om prikken er rekursiv er et empirsk spørgsmål. Nominaliseringer som 'selv-op-ofrelse' $(\leftarrow$ ?ofre (sig) selv ${ }^{\mathrm{P}} \mathrm{op}^{\mathrm{P}}$ ) kan tolkes i den retning.

18 Dette er 'displacement'-problemet, et spørgsmål Chomsky naturligvis behandler og diskuterer mange steder. Et af de mere underholdende er Chomsky (2000: 23ff).

19 Thrane (1983) er et tidligt bidrag til klarlæggelse af disse forhold, men i en noget anden forskningsmæssig kontekst.

20 Den sidste 'klassiske' sekundære verbalkateori, diatese, falder ind under informationsstrukturlaget. 